\title{
HOUSING MARKET DYNAMICS UNDER A PEGGED EXCHANGE RATE - A STUDY OF HONG KONG
}

\author{
Ka Hung $\mathrm{YU}^{1, *}$, Eddie Chi Man HUI ${ }^{1}$ \\ ${ }^{1}$ Department of Building and Real Estate, The Hong Kong Polytechnic University, Hong Kong, China
}

Received 26 December 2015; accepted 13 January 2017

\begin{abstract}
This study explores the major determinants of prices and rents of properties in the mass housing market and in the luxury housing market of Hong Kong. The findings show that property price (and rental) dynamics are primarily driven by demand factors, rather than by housing supply. While macroeconomic factors and the provision of subsidized homeownership, to varying degrees, influence housing prices and/or rents, it is the result of U.S. monetary policy which has directly (through changes in money supply) and indirectly (through the wealth effect from a bullish stock market fuelled by unconventional monetary policy such as Quantitative Easing (QE) triggered the current affordability issue. Some policy implications with reference to recent U.S. monetary policy developments as well as to the Linked Exchange Rate System between Hong Kong Dollar and U.S. Dollar are then discussed.
\end{abstract}

Keywords: housing market dynamics, market fundamentals, stock market, assisted homeownership, housing supply, U.S. monetary policy.

Supplementary material associated with this article can be found, in the online version, at https://doi.org/10.3846/ijspm.2018.441

\section{Introduction}

The housing affordability problem has arguably been the most vigourously-debated social issue in Hong Kong. On the one hand, property prices and rents have been soaring continuously since 2004 (Figures 1 and 2). From an international perspective, it is shown through a comparison with five other Asian cities, namely Singapore, Seoul, Taipei, Tokyo, and Shanghai that Hong Kong's property prices, similar to housing prices in Shanghai and in Taipei, have undergone much more rapid growth especially after the Financial Crisis of 2008, when compared with the property price trends in Singapore, Seoul, and Tokyo (Figure 3). The surging property prices and rents, if anything, has made housing increasingly unaffordable for many Hong Kong residents, since their income growth has not been able to keep up with the upward price/rental movements ${ }^{1}$.

Not surprisingly, property developers (for not supplying enough housing units) and the government (for not providing enough land for residential development as sole

1 According to the $11^{\text {th }}$ Annual Demographia International Housing Affordability Survey (2015), Hong Kong's price-toincome ratio is 17.0 , considered the least affordable housing market among the 378 metropolitan markets in 9 countries.

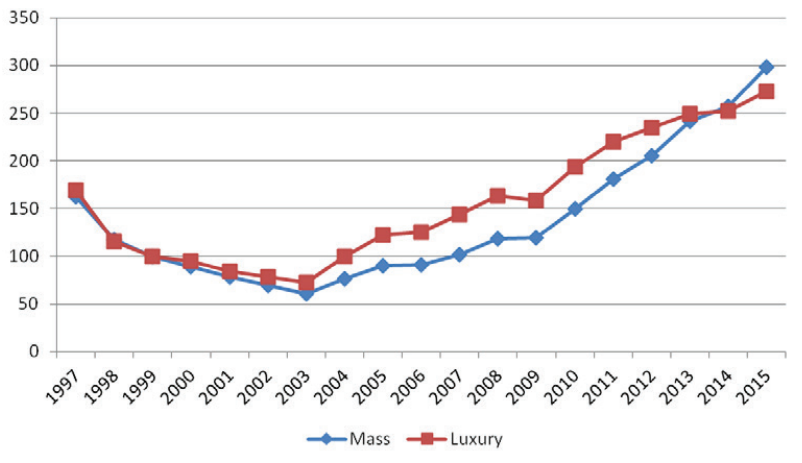

Figure 1. Residential property price indices for mass (Classes $\mathrm{A}, \mathrm{B}$, and C) and luxury (Classes D \& E) housing markets, 1997-2015 (source: Rating and Valuation Department)

Note: $1999=100$

owner of all land in Hong Kong) have been blamed for this predicament. These claims appear to be well-founded, as housing supply has been noticeably lower since 2003 and much less developable land (in $\mathrm{m}^{2}$ ) has been sold after 2000 in comparison with the 1990s (Figures 4 and 5). Expectedly, the general public calls for the supply of more housing units in both the private and public sectors ${ }^{2}$.

2 As well as the supply of more developable land by the government.

*Corresponding author. E-mail: 13900181r@connect.polyu.hk 


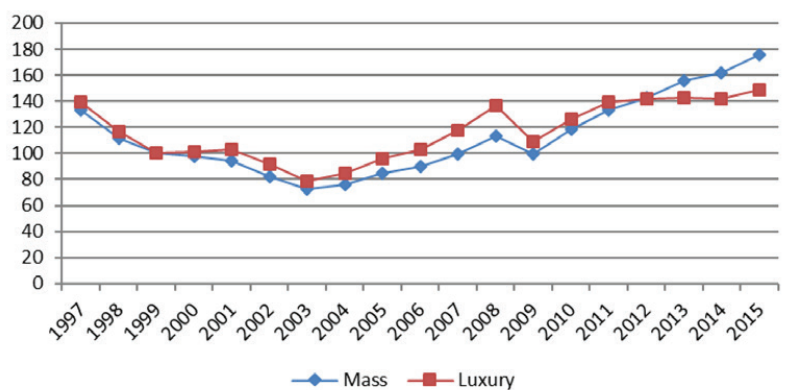

Figure 2. Residential property rental indices for mass (Classes $\mathrm{A}, \mathrm{B}$, and C) and luxury (Classes D \& E) housing markets, 1997-2015 (source: Rating and Valuation Department)

Note: $1999=100$

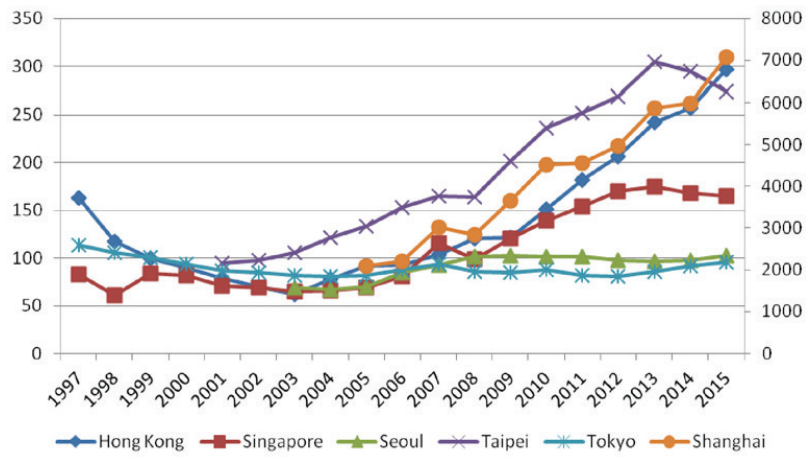

Figure 3. Property price indices of six major Asian cities, 1997-2015

(sources: Ratings \& Statistics Department [Hong Kong], Singapore Real Estate Exchange [Singapore], Korean Statistical Information Service [Seoul], Sinyi Realty Inc. [Taipei], Japan Real Estate Institute [Tokyo], and China Real Estate Index System [Shanghai])

Notes: 1) Property price index (Hong Kong): $1999=100$;

2) Property price index (Singapore): January $2009=100$;

3) Property price index (Seoul): June $2015=100$; 4) Property price index (Taipei): 2001Q1 $=100 ; 5)$ Property price index (Tokyo): $2000 Q 1=100 ; 6$ ) Property price index (Shanghai): December 2005 (in Beijing) $=1000$

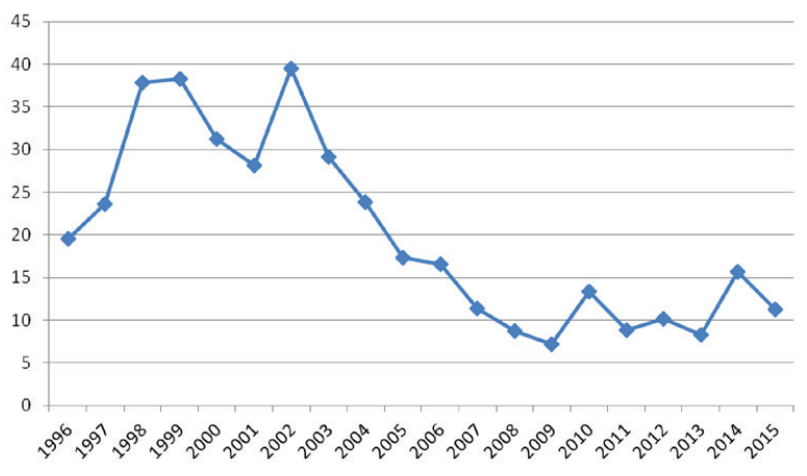

Figure 4. New supply of residential units from 1996 to 2015 (in thousand units) (source: Buildings Department)

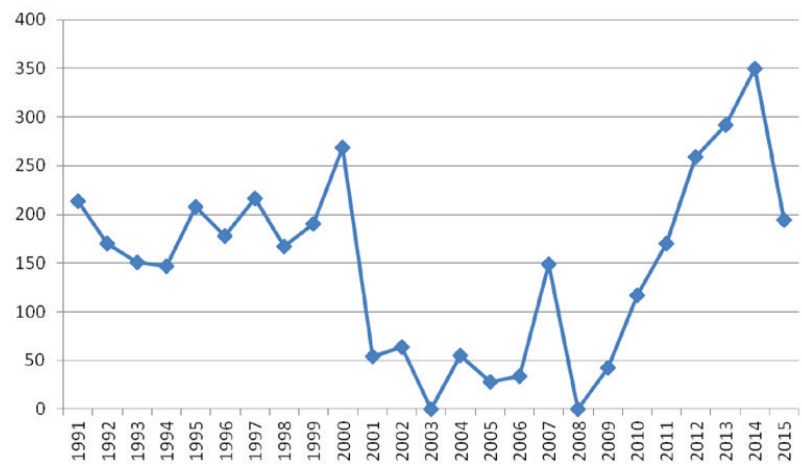

Figure 5. Supply of land for residential development from 1991 to 2014 (in thousand $\mathrm{m}^{2}$ ) (source: Lands Department)

This, however, completely overlooks the demand side of the housing market. Besides market conditions and demographic factors, three particular elements stand out with regard to their latent effects on the demand for housing in Hong Kong. The first element is the provision of subsidized homeownership, known as the Home Ownership Scheme (HOS). As will be discussed in the literature review section, the supply of assisted homeownership has been found to incur impacts on the demand for private housing.

The second element concerns the stock market. It has been documented that additional housing demand can be generated as a result of the wealth effect, due to capital gains from the stock market ${ }^{3}$. Additionally, real estate is also regarded as one of the asset classes in investors' portfolios. In other words, stock market movements could result in profound implications as regards Hong Kong's housing demand, and by extension, housing prices/rents.

The last element is the influence of U.S. monetary policy. The Hong Kong Dollar (HKD), since October 1983, has been pegged to the U.S. Dollar (USD) under a "hard peg" currency board arrangement known as the Linked Exchange Rate system, under which the exchange rate between HKD and USD is officially set at $1 \mathrm{USD}=7.8 \mathrm{HKD}$ with a convertibility zone between $7.75-7.85 \mathrm{HKD}$ to $1 \mathrm{USD}^{4}$. In order to maintain the exchange rate within this zone ${ }^{5}$, the Hong Kong Monetary Authority (HKMA) has to follow whatever monetary policy change initiated by the Federal Reserve, as shown in the similarities in the

3 This new-found capital, hence, can be used to settle at least the downpayment for, if not the full amount of, housing units.

4 According to the HKMA, it "undertakes to buy US dollars from licensed banks at HK\$7.75 to one US dollar (strong-side Convertibility Undertaking) and sell US dollars at HK\$7.85 to one US dollar (weak-side Convertibility Undertaking)."

5 Even the HKMA admits that, "the Link ties Hong Kong to US monetary policy at times when the economic cycles of Hong Kong and the US may not necessarily be moving in tandem. A Linked Exchange Rate system leaves little scope for an autonomous interest rate policy to achieve the objectives of price stability or promotion of economic growth." 
movements of the Federal Funds Rate and of Hong Kong's base interest rate (Figure 6). With the U.S. Federal Funds Rate falling to near-zero levels in the aftermath of the 2008 global financial crisis, this means that businesses and individuals (including potential homebuyers) in Hong Kong, owed to the pegged currency, can easily obtain much cheaper loans from banks than they otherwise could have under a floating exchange rate system ${ }^{6}$.

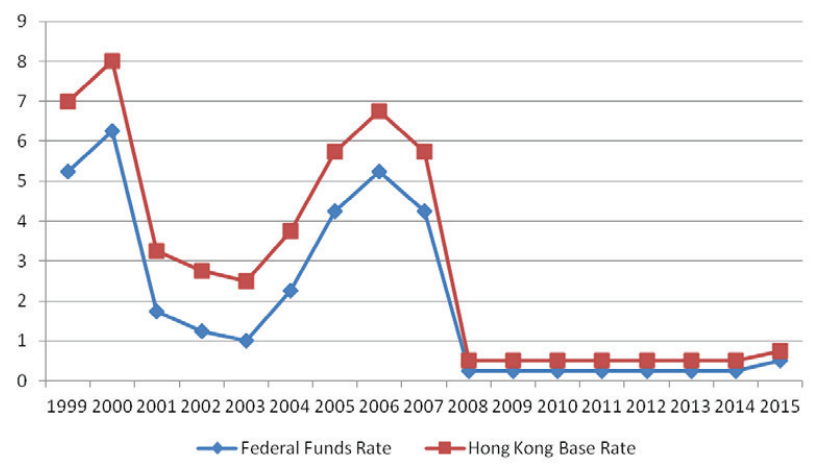

Figure 6. U.S. Federal Funds rate and Hong Kong base rate, 1999-2014 (Year-end figures; in \%)

(sources: The Federal Reserve \& HKMA)

These factors give rise to the following questions:

- Are the property price and rental trends supply- or demand-driven?

- What are the major driving forces of housing prices and rents?

- Does Hong Kong's assisted homeownership programme play a role in its private property price/ rental adjustments? and

- Do U.S. monetary policy changes trigger the city's housing price/rental movements? If so, how?

In response to these questions, this research study aims to explore the major driving forces behind the dynamics of Hong Kong's housing market (i.e. both housing prices and rents), between the $4^{\text {th }}$ quarter of 1983 and the $2^{\text {nd }}$ quarter of 2015.

The remainder of this paper is presented as follows: After this introduction section, relevant literature with regard to the demand for housing, as well as how the availability of assisted homeownership affects the private housing market is to be discussed. Following the literature review is the section in which the methodology and the data necessary for this investigation are to be presented. Then, the empirical findings are to be presented and discussed. Prior to the final section which concludes the study, some policy implications based upon the findings are to be discussed.

6 With reference to the pegged exchange rate, it is worth noting that both the New Taiwan Dollar (unofficially) and Renminbi (officially) are also pegged to the U.S. Dollar; and that the upward trends in property prices for both Shanghai and Taipei highly resemble Hong Kong's property price movements as well (see Figure 3).

\section{Literature review}

Homeownership in the private sector 1) is regarded as the final step to make on the housing ladder for a household; 2) confers social status; 3 ) helps create one's sense of belonging to a particular place; and 4) guarantees a shelter for retired persons and keeps the elderly from poverty ( $\mathrm{Ri}$ takallio, 2003). What distinguishes private properties from those in the public sector is that the quality of the former is generally higher and it reflects a more exclusive lifestyle (Teo \& Kong, 1997).

While the ontological meanings of homeownership have been brought up in the discussions of the rationale behind homeownership (see Saunders, 19907), the majority of previous studies, instead, have focused on housing tenure choice from an economic perspective. Households are usually regarded as economically-rational and make housing tenure decisions to maximize utility, subjected to their budget constraints (Arnott, 1987). It should be noted, however, that a household's utility towards housing depends on consumption demand and investment demand $^{8}$ (Henderson \& Ioannides, 1983, 1987; Berkovec, 1989; Brueckner, 1997; C. C. Lin \& S. J. Lin, 1999; Arrondela \& Lefebvreb, 2001; Cassidy, Dennis, \& Yang, 2008). According to Henderson and Ioannides (1983, 1987), if a household's investment demand for housing is higher than its consumption demand, it tends to become owner-occupiers. Otherwise, it becomes renters 9 . Nevertheless, in the Henderson-Ioannides housing tenure model, an investment constraint is assumed for homebuyers, in that the quantity of housing owned is at least as much as the quantity of housing consumed. In accordance with Bruecker (1997), consumption demand and investment demand for housing become intertwined, as tenure choice and housing demand are essentially decided together (also see Lin, 1990, 1994). With the binding investment constraint, one issue arises as the optimal investment portfolio of the homeowner is not efficient, due to overinvestment in housing (Bruecker, 1997) ${ }^{10}$. Also, as the transaction cost and information cost for housing

\footnotetext{
7 For the criticisms of Saunders' (1990) notion of homeownership, see Forrest, Murie, and Williams (1990) and La Grange and Pretorius (2000).

8 In addition to price appreciations, real property is usually seen as a hedge against inflation (G. S. Sirmans \& C. F. Sirmans, 1987; Chen \& Patel, 2002; Hoesli, Lizieri, \& MacGregor, 2008), in that high inflation rates on a regular basis render housing a desirable asset for many investors. In addition, homeownership is closely tied to many households' retirement strategy even though they may find properties not very affordable (Lee, 1996).

9 Renting also becomes a more attractive option should housing prices fluctuate (Henderson \& Ioannides, 1983).

${ }^{10}$ This observation is corroborated in a study of Taiwan's housing market by Lin, C. C. and Lin, S. J. (1999), in which it is reported that, for a household which only owns one house, the ratio of its investment motive to its consumption motive is approximately $74: 26$.
} 
are higher than other financial products, it is suggested by Case and Shiller (1989) and Linneman (1986) that any potential profits obtained from homeownership could be dissipated. On the other hand, renters, albeit not being bound by the investment constraint, are subject to what Henderson and Ioannides $(1983,1987)$ label the "renter externality", as higher cost is incurred as a result of utilization. Besides, as the homeowner's imputed rental income is not taxable, renters, in a sense, do not benefit from the tax subsidy exclusive to owner-occupiers ${ }^{11}$.

Assume a household's investment motive outweighs its consumption motive, two elements are critical in a home-purchase decision: affordability and mortgage payments (Ong, 2000). For the former income has generally been considered the most important determinant of housing prices (AETM, 1991; Bourassa \& Hendershott, 1995; Whitehead, 1974; Buckley \& Ermisch, 1982; Stern, 1992; Munro \& Tu, 1996). However, as purchasing a home, in general, is a long-term process which requires mortgage financing, the expected permanent income, not temporary income changes, shapes housing demand (AETM, 1991; Pain \& Westaway, 1997). Permanent income requires stability of the economy, and low unemployment rates are usually perceived as a reflection of economic stability and the prosperity of permanent income of a country (or city). Interestingly, the effect of economic conditions on private residential activities is mixed. While several studies have reported significant linkages between GDP and housing prices (Case, Goetzmann, \& Rouwenhorst, 1999; Goodhart \& Hofmann, 2008), Bardhan, Datta, Edelstein, and Lum (2003) are unable to identify significant impacts in this regard.

For the latter, mortgage housing finance essentially dictates a potential homebuyer's user cost ( $\mathrm{Tu}, 2000)$. When the user cost of homebuyer is sufficiently low, homeownership rates are usually high (La Grange \& Pretorius, 2000 $)^{12}$. In addition, as mortgages are based upon nominal mortgage rates, this indicates that nominal interest rate, rather than real interest rate ${ }^{13}$, plays a critical role in affecting the user cost of homeownership, hence a

\footnotetext{
${ }^{11}$ This argument, however, does not apply to Hong Kong, as homeowners are subject to a type of property tax known as Rates, regardless of whether they lease the property out in exchange of a rental income or occupy it themselves.

12 Another condition contributing to high ownership rates is sufficiently high returns to housing investment, which create wealth for households and have positive impacts on consumer spending (Skinner, 1989; Manchester \& Poterba, 1989; Bosworth, Burtless, \& Sabelhaus, 1991).

${ }^{13}$ Even though previous studies such as Gibson (1972), Schwab (1983), Hui and Yiu (2003), and Yiu (2009) have found significant negative relationships between real interest rate and property returns, they primarily view real properties as an investment asset, this topic is not the focus of this study, which investigates property (as both a commodity for use as well as an investment asset) price/rental dynamics with reference to the Linked Exchange Rate system.
}

household's affordability and the resultant housing prices (Drake, 1993; Ling \& Narnjo, 1995; Jin \& Zeng, 2004; Beltratti \& Morana, 2010).

Aside from affordability and mortgage finance, there is an extensive literature devoted to 1) the risk-return characteristics of real properties in comparison to other investment assets such as stocks and bonds (Zerbst \& Cambon, 1984); and 2) the effect of monetary policies. For the former, real stock returns have been found to contain information concerning real economic activities prior to their actual occurrences (Geske \& Roll, 1983; Kaul, 1987; Fama, 1990). With a different focus, Ito and Iwaisako (1995), in their study of Japan stock market and real estate market from 1956 to 1993, discovered 1) noticeable correlations between stock price movements and land price movements, and 2) correlations between asset prices and market fundamentals, but only between mid1987 and mid-1989.

For the latter, in addition to interest rate adjustments, another form of monetary policy is through adjustments in money supply. An expansion in money supply brings about a higher general price level of goods and services, including housing. Higher housing price induces not only a wealth effect which encourages further spending by households, but also a collateral effect which improves households' borrowing capacity ${ }^{14}$ (Goodhart \& Hofmann, 2008). Besides, a higher money supply also enhances the availability of bank credit at lower interest rates, which further triggers the demand for credit, especially from prospective homeowners who were hitherto borrowingconstrained. Numerous studies have provided empirical support for the linkages between money supply and housing prices (see Darrat \& Glascock, 1989; Breedon \& Joyce, 1992; Kim, 1993; Ball, 1994; Maclennan, Muellbauer, \& Stephens, 1998; Lastrapes, 2002; Aoki, Proudman, \& Vlieghe, 2004; Jin \& Zeng, 2004; Iacoviello, 2005; Chen, Tsai, \& Chang, 2007; Chen, Chang, Yang, \& Hsieh, 2012; Elbourne, 2008; Goodhart \& Hofmann, 2008; Beltratti \& Morana, 2010).

Nevertheless, these studies, as valuable and insightful as they are, have focused on nations without the provision of subsidized homeownership. If government institutions get involved in the property market, by either proffering public housing or promoting subsidized homeownership (Forrest \& Murie, 1988; Ching \& Tyabji, 1991; Bacher, 1993; Pickvance, 1994; Hays, 1994; Balchin, 1996), housing-related decisions change as a result. The provision of subsidized ownership housing 1) distorts the existing housing market mechanisms; and 2) differentiates households' affordability and housing preferences of households.

Some previous studies have focused on how the public housing sector interacts with the private housing sector, as well as with different economic factors. For the former,

\footnotetext{
${ }^{14}$ However, higher property price also leads to negative income effect for renters (i.e. higher rents) and for first-time homebuyers (i.e. higher downpayment).
} 
the interrelations between private housing price and public housing price have been found (Phang \& Wong, 1997; Ong \& Sing, 2002), despite varying interpretations as to 1) the nature of their relationships and 2) the role played by assisted homeownership. Two hypotheses have been formed. The first hypothesis, known as the market forces hypothesis, indicates that since public housing is more regulated than private housing, the former is less responsive to economic forces than the latter (Ong \& Sing, 2002). Instead, the prices of public housing in its resale market, according to Tu (2002) and Tu, Kwee, and Yuen (2002), are largely dictated by government housing policies. Also, as the private housing market tends to respond to changes sooner, private housing returns tend to lead public housing returns. The other hypothesis, known as the upgrading hypothesis, states that upward price movements in public housing flats, along with changes in both income and interest rates, enable subsidized homeowners to own homes in the private sector (Lum, 1996; Ong, 1999; Hui, Yu, \& Ho, 2009; Ong, 2000). Under such mechanism, price adjustments in the public housing market should be positively related with those in the private housing market (see Phang \& Wong, 1997).

Having discussed the relevant literature, the next section describes the research methodology and the data necessary for conducting this study.

\section{Methodology and data}

A series of housing market models which consist of various housing demand factors as well as housing supply are to be established. The key variables to be explored with the model are the residential property price index (PPI) and the residential property rental index (PRI) compiled by the Rating \& Valuation Department (RVD) ${ }^{15}$.

In this study, separate investigations on several housing classes, based upon the saleable area of housing units, are to be conducted. According to the RVD, all housing units in Hong Kong are divided into five classes, namely:

- Class A: Less than $40 \mathrm{~m}^{2}$;

- Class B: $40 \mathrm{~m}^{2}-69.9 \mathrm{~m}^{2}$;

- Class C: $70 \mathrm{~m}^{2}-99.9 \mathrm{~m}^{2}$;

- Class D: $100 \mathrm{~m}^{2}-159.9 \mathrm{~m}^{2}$; and

- Class E: $160 \mathrm{~m}^{2}$ or above.

Classes A, B, and C are usually referred to as the mass housing market, whereas Classes $\mathrm{D}$ and $\mathrm{E}$ are regarded as the luxury housing market. While the mass market is to be studied in separate models, the luxury housing market, due to fewer transactions especially in the $1980 \mathrm{~s}^{16}$, is to

\footnotetext{
${ }^{15}$ One advantage of using these indices, rather than per unit prices and rents, is that by referencing the rateable value of the property, the residential property price/rental indices measure price/rental changes while controlling for any latent changes in terms of the quality of the assessed premises.

${ }^{16}$ It was until 1993 that separate property price indices for Class D flats and Class E housing units were available.
}

be explored in one single model (i.e. with PPI [Classes D and E] and PRI[D] as the key variables).

For factors that influence the demand for housing, according to Malpezzi (1996), housing demand is a function of the following factors: 1) housing price; 2) income variables; 3) wealth variables; and 4) demographic variables. In short, Malpezzi's model covers both consumption demand and investment demand for housing.

For the consumption demand factors, a number of market fundamentals are to be considered. Among those is the amount of households ( $\mathrm{HH})$ in Hong Kong. The other market fundamentals considered in the model, by contrast, are mostly macroeconomic factors. The first factor is Hong Kong's real GDP (GDP) ${ }^{17}$. Ideally, as seen in the literature, median household income has been used in housing price models in attempt to assess the housing affordability situation. Nonetheless, owed to the unavailability of data in this regard that covers the whole study period of this research ${ }^{18}$, Hong Kong's real GDP is then selected as an alternative in depicting Hong Kong's economic conditions. In addition to real GDP, as housing, similar to other investment tools, is regarded by some as a hedge against inflation, Hong Kong's inflation situation, represented by the year-on-year changes in the Composite Price Index (CPI), is to be included in the model as one of the factors which potentially affects the demand for housing.

For the investment demand factors, as the demand for housing has been found to be subject to possible wealth effect, stock market returns and housing demand (hence housing prices/rents) are likely to be positively correlated. Hence, the stock market variable, represented by the quarterly movements in the Hang Seng Index (HSI), is incorporated into the housing market models. As for the stock market volatility, a proxy variable (RISK) which equals:

RISK $=\frac{\text { Standard deviation of daily Hang Seng Index movements at time } t}{\text { Hang Seng Index at the end of time } t-1}$.

is to be included, with the aim to explore its impacts, if any, on both property prices and rents.

However, Malpezzi's (1996) housing demand model does not consider two major elements unique to Hong Kong: 1 ) the provision of subsidized homeownership and 2) the latent effect of U.S. monetary policy adjustments via the Linked Exchange Rate system. For the former, though serving as an alternative to private housing, assisted homeownership has actually been found in numerous Singaporean housing studies (Lum, 1996; Ong, 1999; Hui et al., 2009; Ong, 2000) to engender additional demand for

\footnotetext{
17 This is defined by Hong Kong's Census and Statistics Department as GDP in chained (2013) dollars (HK\$ million).

${ }^{18}$ Only median household income in Hong Kong after 1999 is currently available. Besides, there exist some fundamental issues concerning the Census and Statistics Department's computation of median wages, resulting in some highly inconsistent figures for which in the early 1990s.
} 
private housing units, through profits obtained from the transactions of these subsidized housing units in the resale market. This is known as the upgrading hypothesis. Does this hypothesis hold for Hong Kong, in which subsidized homeownership is proffered? To address this question, the total amount of HOS flats transacted (HOS; including both first-hand and resale markets) is thus incorporated in the housing market models for Classes A, B, and C flats ${ }^{19}$. Should the upgrading hypothesis hold, a positive effect on housing prices/rents is expected.

Another element is U.S. monetary policy influences via the pegged exchange rate arrangement. There are two channels through which Hong Kong would be affected by U.S. monetary policy, namely adjustments in 1) the Federal Funds Rate (FED) and 2) money supply. Any decisions to adjust either by the Federal Reserve lead to similar actions by the HKMA in order to keep the HKD within the Convertibility Zone. Nevertheless, while changes in FED normally have implications on changes in money supply, the opposite is not necessarily true in view of the massive increase in money supply via $\mathrm{QE}$ without any changes in FED due to the Zero Interest Rate Policy (ZIRP). Therefore, rather than FED, Hong Kong's money supply $\left(\mathrm{Ml}^{20}\right)$ is included in the models instead.

Additionally, the supply of housing (HS), denoted by the amount of newly-completed housing units in the private sector, is to be included. This is to test whether or not the notion of "higher housing supply mitigates the current housing affordability problem", as widely perceived by the public, holds.

Last but not least, two dummy variables (AFC and SARS) which affect not only Hong Kong's housing market, but also its stock market and its whole economy are introduced to control the impact of exogenous shocks to property prices and rents, as follows:

\footnotetext{
${ }^{19}$ The reason these two variables are being excluded in the model for Classes D and E flats is that an income/asset limit has been set by the Housing Authority to decide one's eligibility for HOS flats. It is highly unlikely that households who could afford housing in the luxury market are able to meet these eligibility requirements, even though they are technically able to purchase resale HOS flats in the open market in which no income/asset limits apply.

${ }^{20}$ The reason M1, rather than broader definitions of money supply such as M2 and M3, is chosen is because, unlike nations under a floating exchange rate regime, the Hong Kong Monetary Authority, under the existing Currency Board system, needs to adjust Hong Kong's monetary base, through the foreign reserves in its possession, with the aim to keep the Hong Kong Dollar-U.S. Dollar exchange rate within the Convertibility Zone. Ideally, monetary base data would be a better choice for this particular investigation, as broader definitions of money supply could change even without any adjustments in monetary base. However, as only the monetary base data from 1999 to 2016 is available, M1, by definition, is the closest alternative, considering the link between M1 and Monetary base (see Garfinkel \& Thornton, 1989).
}

\section{Dummy variable 1: Asian Financial Crisis (AFC) (1997:3-1998:4)}

The Asian Financial Crisis, which took place between July 1997 and December 1998, began with the currency crisis in Thailand on $2^{\text {nd }}$ July 1997. No longer able to defend the Thai Baht, which looks to have been overpriced, against speculative attacks, the Thai government adopted a floating exchange rate for Baht, which plummeted instantly. This was then followed by the drastic depreciation of currencies in Singapore, Taiwan, South Korea, and Malaysia (Figure 7$)^{21}$. HKD was also subject to similar attacks, but eventually managed to maintain the pegged exchange rate through a massive increase in short-term interest rate (Corsetti, Pesenti, \& Roubini, 1999). Following the financial turmoil in these Asian nations, the effects of the AFC appear to have been spilled over to Russia, which eventually defaulted on its sovereign debts in 1998. Economic situations of these countries began to recuperate from the shocks of the AFC by early 1999 .

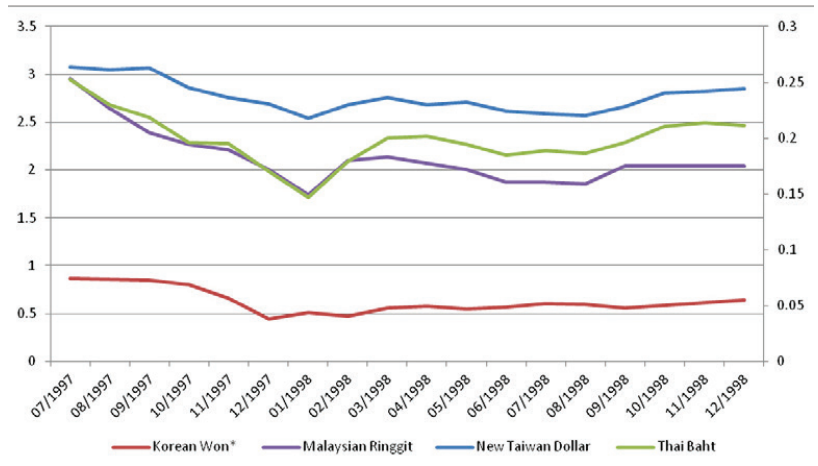

Figure 7. Exchange Rates between Hong Kong Dollar and currencies of East Asian nations between 1997:3 and 1998:4 (source: The Hong Kong Monetary Authority)

Note: * Per 100 units

\section{Dummy variable 2: SARS (2003:1-2003:2)}

The Severe Acute Respiratory Syndrome (SARS) is a thenunknown epidemic that had ravaged Hong Kong from February 2003 to June 2003. Although SARS originated from Guangdong Province of Mainland China back in late 2002, it was until March of 2003 that the first confirmed case of SARS occurred in Hong Kong ${ }^{22}$. According to the expert committee report commissioned by the HKSAR government (2003), the epidemic soon spread not only within Hong Kong ${ }^{23}$, but also to Singapore, Canada, and

${ }^{21}$ The only exception appears to have been China's Renminbi, which had previously depreciated against the U.S. Dollar in 1994.

${ }^{22}$ When a professor from Guangzhou "who had been treating atypical pneumonia cases in a Guangzhou Hospital visited Hong Kong and stayed at a hotel in the Kowloon District in Hong Kong (Lee, 2003, p. 652)”.

${ }^{23}$ Particularly at Amoy Gardens in East Kowloon in early April 2003. 
Vietnam. Hong Kong was subsequently listed by the World Health Organization as an area with recent transmission of SARS until June 23, 2003. This event had incurred not only losses of human lives (300 deaths in 1,755 confirmed cases), but also adverse effects on Hong Kong's economy (Siu \& Wong, 2004).

A description of these variables and the expected relationships between them and PPI/PRI is provided in the Table 1.

These variables are incorporated into a Vector $\mathrm{Au}-$ toregressive (VAR) Model, which forms the basis of the housing market models. However, prior to that, the is- sue concerning the stationarity of the variables is to be addressed first. In order to avoid the statistical problem known as spurious regressions which result in biased estimations, the selected variables are required to be stationary. Yet, most macroeconomic and finance variables are notorious for being non-stationary unless they are at least first-differenced. As a result, unit root tests are first performed to test for the stationarity of the selected variables. The results, as reported in Table 2, show that the selected variables, with the exception of stock market volatility, are deemed stationary after first-differencing. Therefore, they are inserted in the VAR models in first-differenced forms.

Table 1. Description of selected variables

\begin{tabular}{|c|c|c|}
\hline Variable(s) & Description & $\begin{array}{l}\text { Expected relationship with } \\
\text { property prices/rents }\end{array}$ \\
\hline \multicolumn{3}{|c|}{ Dependent variables (Property price/Rental indices) } \\
\hline LnPPI(A) \& LnPRI(A) & $\begin{array}{l}\text { Property price index and Property rental index of Class A housing } \\
\text { units (in natural log form) }\end{array}$ & / \\
\hline LnPPI(B) \& LnPRI(B) & $\begin{array}{l}\text { Property price index and Property rental index of Class B housing } \\
\text { units (in natural log form) }\end{array}$ & I \\
\hline $\operatorname{LnPPI}(\mathrm{C}) \& \operatorname{LnPRI}(\mathrm{C})$ & $\begin{array}{l}\text { Property price index and Property rental index of Class C housing } \\
\text { units (in natural log form) }\end{array}$ & I \\
\hline LnPPI(D\&E) \& LnPRI(D) & $\begin{array}{l}\text { Property price index and Property rental index of housing units in } \\
\text { the luxury market (in natural log form) }\end{array}$ & I \\
\hline \multicolumn{3}{|c|}{ Explanatory variables } \\
\hline \multicolumn{3}{|c|}{ Macroeconomic variables } \\
\hline LnHH & Number of households in natural log form & + \\
\hline LnGDP & Hong Kong's real GDP (in 2013 chained dollars) in natural log form & + \\
\hline CPIC & Year-on-year change in the Composite Price index (in \%) & + \\
\hline \multicolumn{3}{|c|}{ U.S. monetary policy variables } \\
\hline LnM1 & Money supply in Hong Kong in natural log form & + \\
\hline \multicolumn{3}{|c|}{ Stock market variables } \\
\hline LnHSI & Hang Seng Index in natural log form & + \\
\hline RISK & Stock Market volatility (in \%) & - \\
\hline \multicolumn{3}{|c|}{ Housing-related variables } \\
\hline LnHS & Amount of newly-completed residential units (in natural log form) & - \\
\hline HOS & $\begin{array}{l}\text { Amount of HOS units transacted either in the first-hand market or } \\
\text { in the resale market }\end{array}$ & - \\
\hline \multicolumn{3}{|c|}{ Exogenous variables } \\
\hline AFC & $\begin{array}{l}\text { Exogenous dummy variable depicting the Asian financial crisis } \\
(1997: 3-1998: 4)\end{array}$ & - \\
\hline SARS & $\begin{array}{l}\text { Exogenous dummy variable depicting the outbreak of the Severe } \\
\text { acute respiratory syndrome }(2003: 1-2003: 2)\end{array}$ & - \\
\hline
\end{tabular}

Table 2. The Augmented Dickey-Fuller test results

\begin{tabular}{|l|l|c|c|}
\hline \multicolumn{2}{|c|}{ Variable } & $\begin{array}{c}\text { ADF test statistic } \\
\text { (Intercept) }\end{array}$ & $\begin{array}{c}\text { ADF test statistic } \\
\text { (Trend and Intercept) }\end{array}$ \\
\hline \multirow{2}{*}{ LnPPI(A) } & Level & -1.062 & -1.750 \\
\cline { 2 - 4 } & 1 1st difference & $-5.082^{\star}$ & $-5.061^{\star}$ \\
\hline \multirow{2}{*}{ LnPPI(B) } & Level & -1.294 & -1.798 \\
\cline { 2 - 4 } & 1 1st difference & $-5.688^{\star}$ & $-5.679^{\star}$ \\
\hline
\end{tabular}


End of Table 2

\begin{tabular}{|c|c|c|c|}
\hline \multicolumn{2}{|c|}{ Variable } & $\begin{array}{l}\text { ADF test statistic } \\
\text { (Intercept) }\end{array}$ & $\begin{array}{c}\text { ADF test statistic } \\
\text { (Trend and Intercept) }\end{array}$ \\
\hline \multirow{2}{*}{ LnPPI(C) } & Level & -1.681 & -1.986 \\
\hline & 1st difference & $-6.125^{\star}$ & $-6.163^{\star}$ \\
\hline \multirow[t]{2}{*}{ LnPPI(D\&E) } & Level & -1.699 & -2.115 \\
\hline & 1st difference & $-6.174^{\star}$ & $-6.226^{*}$ \\
\hline \multirow[t]{2}{*}{ LnPRI(A) } & Level & -1.494 & -1.785 \\
\hline & 1st difference & $-5.765^{\star}$ & $-5.759^{*}$ \\
\hline \multirow[t]{2}{*}{$\operatorname{Ln}(\mathrm{PRI}(\mathrm{B})$} & Level & -1.660 & -1.922 \\
\hline & 1st difference & $-5.828^{\star}$ & $-5.831^{\star}$ \\
\hline \multirow[t]{2}{*}{ LnPRI(C) } & Level & -2.104 & -2.122 \\
\hline & 1st difference & $-5.964^{\star}$ & $-6.018^{\star}$ \\
\hline \multirow[t]{2}{*}{ LnPRI(D) } & Level & -2.401 & -2.268 \\
\hline & 1st difference & $-5.923^{\star}$ & $-6.057^{\star}$ \\
\hline \multirow[t]{2}{*}{ LnHH } & Level & -1.968 & -0.479 \\
\hline & 1st difference & $-3.885^{\star}$ & $-4.338^{\star}$ \\
\hline \multirow[t]{2}{*}{ LnGDP } & Level & -2.509 & -2.812 \\
\hline & 1st difference & $-5.028^{\star}$ & $-5.430^{\star}$ \\
\hline \multirow[t]{2}{*}{ CPIC } & Level & -1.823 & -1.633 \\
\hline & 1st difference & $-10.36^{*}$ & $-10.340^{*}$ \\
\hline \multirow[t]{2}{*}{ LnHS } & Level & -1.709 & -3.092 \\
\hline & 1st difference & $-14.265^{*}$ & $-14.210^{*}$ \\
\hline \multirow[t]{2}{*}{ LnHSI } & Level & -2.488 & -2.536 \\
\hline & 1st difference & $-10.986^{*}$ & $-11.173^{\star}$ \\
\hline \multirow[t]{2}{*}{ RISK } & Level & $-8.925^{*}$ & $-9.461^{*}$ \\
\hline & 1st difference & $-8.454^{*}$ & $-8.417^{\star}$ \\
\hline \multirow[t]{2}{*}{ HOS } & Level & -2.190 & $-12.333^{\star}$ \\
\hline & 1st difference & $-13.584^{\star}$ & $-13.538^{\star}$ \\
\hline \multirow[t]{2}{*}{ M1 } & Level & -0.651 & -1.908 \\
\hline & 1st difference & $-10.665^{\star}$ & $-10.622^{*}$ \\
\hline
\end{tabular}

Note: * denotes significant at $5 \%$ level.

The resultant VAR models for the mass housing market, thus, take the following form:

$$
\begin{aligned}
& \Delta \operatorname{PPI}(\mathrm{A} / \mathrm{B} / \mathrm{C})_{\mathrm{t}}=\mathrm{c}+\sum_{\mathrm{i}=0}^{\mathrm{n}} \mathrm{b}_{1 \mathrm{i}} \Delta \operatorname{PPI}(\mathrm{A} / \mathrm{B} / \mathrm{C})_{\mathrm{t}-\mathrm{i} 1}+\sum_{\mathrm{i}=0}^{\mathrm{n}} \mathrm{b}_{2 \mathrm{i}} \Delta \ln H \mathrm{H}_{\mathrm{t}-\mathrm{i}}+\sum_{\mathrm{i}=0}^{\mathrm{n}} \mathrm{b}_{3 \mathrm{i}} \Delta \ln \mathrm{GDP}_{\mathrm{t}-\mathrm{i}}+ \\
& \sum_{\mathrm{i}=0}^{\mathrm{n}} \mathrm{b}_{4 \mathrm{i}} \Delta \mathrm{CPIC}_{\mathrm{t}-\mathrm{i}}+\sum_{\mathrm{i}=0}^{\mathrm{n}} \mathrm{b}_{5 \mathrm{i}} \Delta \operatorname{lnHS} \mathrm{t}_{\mathrm{t}-\mathrm{i}}+\sum_{\mathrm{i}=0}^{\mathrm{n}} \mathrm{b}_{6 \mathrm{i}} \Delta \operatorname{lnHSI}_{\mathrm{t}-\mathrm{i}}+\sum_{\mathrm{i}=0}^{\mathrm{n}} \mathrm{b}_{7 \mathrm{i}} \Delta \mathrm{RISK}_{\mathrm{t}-\mathrm{i}}+\sum_{\mathrm{i}=0}^{\mathrm{n}} \mathrm{b}_{8 \mathrm{i}} \Delta \mathrm{HOS}_{\mathrm{t}-\mathrm{i}}+ \\
& \sum_{\mathrm{i}=0}^{\mathrm{n}} \mathrm{b}_{9 \mathrm{i}} \Delta \operatorname{lnM} 1_{\mathrm{t}-\mathrm{i}}+\mathrm{b}_{10} \mathrm{AFC}+\mathrm{b}_{11} \mathrm{SARS}+\varepsilon_{\mathrm{t}}
\end{aligned}
$$

and,

$$
\begin{aligned}
& \Delta \operatorname{PRI}(\mathrm{A} / \mathrm{B} / \mathrm{C})_{\mathrm{t}}=\mathrm{c}+\sum_{\mathrm{i}=0}^{\mathrm{n}} \mathrm{b}_{1 \mathrm{i}} \Delta \operatorname{PRI}(\mathrm{A} / \mathrm{B} / \mathrm{C})_{\mathrm{t}-\mathrm{i}}+\sum_{\mathrm{i}=0}^{\mathrm{n}} \mathrm{b}_{2 \mathrm{i}} \Delta \operatorname{lnHH} \mathrm{H}_{\mathrm{t}-\mathrm{i}}+\sum_{\mathrm{i}=0}^{\mathrm{n}} \mathrm{b}_{3 \mathrm{i}} \Delta \operatorname{lnGDP} \mathrm{H}_{\mathrm{t}-\mathrm{i}}+ \\
& \sum_{\mathrm{i}=0}^{\mathrm{n}} \mathrm{b}_{4 \mathrm{i}} \Delta \mathrm{CPIC}_{\mathrm{t}-\mathrm{i}}+\sum_{\mathrm{i}=0}^{\mathrm{n}} \mathrm{b}_{5 \mathrm{i}} \Delta \operatorname{lnHS} \mathrm{t}_{\mathrm{t}-\mathrm{i}}+\sum_{\mathrm{i}=0}^{\mathrm{n}} \mathrm{b}_{6 \mathrm{i}} \Delta \operatorname{lnHSI} \mathrm{t}_{\mathrm{t}-\mathrm{i}}+\sum_{\mathrm{i}=0}^{\mathrm{n}} \mathrm{b}_{7 \mathrm{i}} \Delta \mathrm{RISK}_{\mathrm{t}-\mathrm{i}}+\sum_{\mathrm{i}=0}^{\mathrm{n}} \mathrm{b}_{8 \mathrm{i}} \Delta \operatorname{HOS}_{\mathrm{t}-\mathrm{i}}+ \\
& \sum_{\mathrm{i}=0}^{\mathrm{n}} \mathrm{b}_{9 \mathrm{i}} \Delta \operatorname{lnM1} \mathrm{ln}_{\mathrm{t}-\mathrm{i}}+\mathrm{b}_{10} \mathrm{AFC}+\mathrm{b}_{11} \operatorname{SARS}+\varepsilon_{\mathrm{t}}
\end{aligned}
$$


Meanwhile, the VAR models for the luxury housing market, which exclude the assisted homeownership factor (HOS), are expressed as follows:

$$
\begin{aligned}
& \Delta \operatorname{PPI}(D \& E)_{\mathrm{t}}=\mathrm{c}+\sum_{\mathrm{i}=0}^{\mathrm{n}} \mathrm{b}_{1 \mathrm{i}} \Delta \operatorname{PPI}(\mathrm{D} \& E)_{\mathrm{t}-\mathrm{i} 1}+\sum_{\mathrm{i}=0}^{\mathrm{n}} \mathrm{b}_{2 \mathrm{i}} \Delta \ln H \mathrm{H}_{\mathrm{t}-\mathrm{i}}+\sum_{\mathrm{i}=0}^{\mathrm{n}} \mathrm{b}_{3 \mathrm{i}} \Delta \ln \operatorname{LDP}_{\mathrm{t}-\mathrm{i}}+ \\
& \sum_{\mathrm{i}=0}^{\mathrm{n}} \mathrm{b}_{4 \mathrm{i}} \Delta C P I C_{\mathrm{t}-\mathrm{i}}+\sum_{\mathrm{i}=0}^{\mathrm{n}} \mathrm{b}_{5 \mathrm{i}} \Delta \ln H S_{\mathrm{t}-\mathrm{i}}+\sum_{\mathrm{i}=0}^{\mathrm{n}} \mathrm{b}_{6 \mathrm{i}} \Delta \ln H S \mathrm{l}_{\mathrm{t}-\mathrm{i}}+\sum_{\mathrm{i}=0}^{\mathrm{n}} \mathrm{b}_{7 \mathrm{i}} \Delta \mathrm{RISK}_{\mathrm{t}-\mathrm{i}}+\sum_{\mathrm{i}=0}^{\mathrm{n}} \mathrm{b}_{8 \mathrm{i}} \Delta \ln M 1_{\mathrm{t}-\mathrm{i}}+ \\
& \mathrm{b}_{9} \mathrm{AFC}+\mathrm{b}_{10} \mathrm{SARS}+\varepsilon_{\mathrm{t}}
\end{aligned}
$$

and,

$$
\begin{aligned}
& \Delta \operatorname{PRI}(\mathrm{D})_{\mathrm{t}}=\mathrm{c}+\sum_{\mathrm{i}=0}^{\mathrm{n}} \mathrm{b}_{1 \mathrm{i}} \Delta \mathrm{PRI}(\mathrm{D})_{\mathrm{t}-\mathrm{i} 1}+\sum_{\mathrm{i}=0}^{\mathrm{n}} \mathrm{b}_{2 \mathrm{i}} \Delta \ln \mathrm{nH}_{\mathrm{t}-\mathrm{i}}+\sum_{\mathrm{i}=0}^{\mathrm{n}} \mathrm{b}_{3 \mathrm{i}} \Delta \operatorname{lnGDP} \mathrm{P}_{\mathrm{t}-\mathrm{i}}+\sum_{\mathrm{i}=0}^{\mathrm{n}} \mathrm{b}_{4 \mathrm{i}} \Delta \mathrm{CPIC}_{\mathrm{t}-\mathrm{i}}+ \\
& \sum_{\mathrm{i}=0}^{\mathrm{n}} \mathrm{b}_{5 \mathrm{i}} \Delta \operatorname{lnHS} \mathrm{t}_{\mathrm{t}-\mathrm{i}}+\sum_{\mathrm{i}=0}^{\mathrm{n}} \mathrm{b}_{6 \mathrm{i}} \Delta \operatorname{lnHSI_{\mathrm {t}-\mathrm {i}}}+\sum_{\mathrm{i}=0}^{\mathrm{n}} \mathrm{b}_{7 \mathrm{i}} \Delta \mathrm{RISK}_{\mathrm{t}-\mathrm{i}}+\sum_{\mathrm{i}=0}^{\mathrm{n}} \mathrm{b}_{8 \mathrm{i}} \Delta \operatorname{lnM1} \mathrm{1}_{\mathrm{t}-\mathrm{i}}+\mathrm{b}_{9} \mathrm{AFC}+\mathrm{b}_{10} \mathrm{SARS}+\varepsilon_{\mathrm{t}}
\end{aligned}
$$

The necessary data is collected from a number of official sources. Firstly, the housing price/rental data is collected from the Rating and Valuation Department. The data of macroeconomic and demographic factors, meanwhile, is compiled from the Census and Statistics Department. As for the investment-related factors, the Hang Seng Index is collected from the Datastream database. For the transactions of HOS units (new and resale), they are retrieved from the Housing Authority. Housing supply data is collected from the Buildings Department. Lastly, money supply data is gathered from the HKMA.

\section{Discussion of findings}

Before running the VAR models, the optimal amount of lagged variables to be included is to be decided. This is determined by the smallest Schwarz Criterion (SC). The results, by means of trial VARs, illustrate that the optimal lag terms that fulfill the aforesaid three conditions, in both the All Classes model and the separate Housing Class models, amount to two (2). The findings of the VAR model(s), consisting of both the impulse response analyses and the variance decomposition analyses ${ }^{24}$ (Tables 3 and $4)$, are to be discussed in the following sections ${ }^{25}$.

\section{Impulse response and variance decompositions analyses}

The findings, from the impulse response analysis, first report significant levels of autocorrelations with property prices/rents, in that current PPI (PRI) movements respond positively to shocks in previous PPI (PRI) adjustments. This means that an upward trend in past property prices (rents) leads to a rise in current property prices (rents)

\footnotetext{
24 The results of the variance decomposition analyses, using levels variables, are shown in Supplementary Appendixes 3 and 4.

${ }^{25}$ For the VAR model results themselves, see the Supplementary Appendixes 1 and 2.
}

(Figures $8 \mathrm{a}$ and 9a). Even though the accumulated impulse responses to lagged PPI (PRI) are similar amongst the different housing sub-markets, previous housing price (rental) movements explain the largest amount of the variances of the current price (rent) for Class A housing, in comparison with other housing classes.

As for the impact of stock market factors, the empirical findings report that shocks from the stock market incur positive responses by both property prices and rents (Figures $8 \mathrm{~b}$ and $9 \mathrm{~b}$ ). Of the four housing sub-classes, the (accumulated) response is the largest for flats in Class D and $\mathrm{E}$, and the smallest for flats in Class A. Also, shocks from stock market movements explain as much as $8 \%$ (10-11\%) of the variances of Classes D and E flats' current property prices (rents) and around 7\% (13-14\%) of the variances of Class $C$ flats' current property prices (rents). Also, it should be noted that the effect of stock market movements on property prices and rents, regardless of housing class, is slightly larger in the shorter-run (i.e. one year) than in the longer-run. These findings, if anything, confirm the presence of the wealth effect in both the sale and the rental sectors, in that capital gains obtained from a bullish stock market generate additional demand for housing, whether for consumption or for investment. Stock market volatility, meanwhile, yields negative responses by property prices (and rents) for Classes B, C, D and E flats, but not for Class A flats in the longer-run (Figures $8 \mathrm{c}$ and $9 \mathrm{c})$. This factor, explaining as much as $2 \%$ of the variances, has a larger impact on the prices of larger housing units (i.e. Class C flats and Classes D and E flats). In the rental sector, however, its effect on Class B flats is actually more pronounced than others (i.e. explaining more than $4.5 \%$ of the variances). Taking these observations into account, it can be said that, while a bullish stock market helps engender additional housing demand for homeownership, stock market volatilities function as a counterweight from the perspective of latent luxury housing homeowners and of latent tenants in Class B housing units. 
The effects of market fundamentals are somewhat mixed. Firstly, shocks in Hong Kong's real GDP result in positive responses by housing prices and rents (particularly in Class B, Figures $8 \mathrm{~d}$ and $9 \mathrm{~d}$ ), meaning that the better Hong Kong's economy performs, property prices and rents rise as a consequence. This is in line with the literature (see Case et al., 1999; Goodhart \& Hofmann, 2008). In addition, real GDP movements explain the highest amount of variances of the prices of flats in Classes B and C and the rents of flats in Class C.

Secondly, the growth in the number of households in Hong Kong is also found to yield positive (accumulated) responses by prices (and rents) of properties in all four subclasses after Period 2 (Figures 8e and 9e). Yet, it should be noted that, this factor manages to explain a much larger amount of variances of property prices than those of property rents (with the exception of luxury housing units). This indicates that household formation is another important factor contributing to new housing demand, particularly for larger housing flats in the ownership sector (Classes D and E).

By contrast, Hong Kong's general price level (CPI) is found to trigger negative property price/rental responses, especially for Classes D and E flats, after Period 2 (Figures $8 \mathrm{f}$ and $9 \mathrm{f}$ ). The negative relationship between property price and CPI reflects that, a growth in Hong Kong's inflation rate results in lower property prices. The findings do not support the notion of real estate as a hedge against inflation (G. S. Sirmans \& C. F. Sirmans, 1987; Chen \& Patel, 2002; Hoesli et al., 2008). Rather, the empirical findings show that physical real estate, functionally, has become very similar to securitized real estate (i.e. as a financial investment), as they both are negatively related to inflation (Hoesli et al., 2008). Of the four housing subclasses, inflation adjustments explain as much as $6 \%$ of the price variances in the luxury housing market, considerably higher than those in the mass housing market. Meanwhile, more than $4 \%$ of rental variances for Class C flats are explained by Hong Kong's general price movements.

As for the effect of assisted homeownership, shocks in the amount of HOS units transacted either in the firsthand market or the resale market generate negative (accumulated) responses by both property prices and rents (Figures $8 \mathrm{~g}$ and $9 \mathrm{~g}$ ), indicating that property prices and rents would fall if more HOS flats are available on the market. This is because assisted homeownership serves as a low-cost alternative for eligible homebuyers, rather than as a means of moving to the private housing sector as indicated by the upgrading hypothesis. A higher supply in HOS flats, effectively, takes a fraction of housing demand from the private housing market, leading to lower property prices (and rents) in the private sector. In accordance with the variance decomposition analysis, this factor helps explain comparatively higher price variances for the smallest private housing flats (i.e. Class A) and relatively higher rental variances for Class B flats.

While the supply of assisted homeownership does influence the price/rental dynamics for smaller housing units, the supply of housing flats in the private sector triggers mixed (accumulated) responses by property prices and rents (Figures $8 \mathrm{~h}$ and $9 \mathrm{~h}$ ). The initial responses in all four housing sub-classes are positive, only to turn negative over time. Only the prices/rents of Class A flats continue to respond positively to housing supply shocks. Despite such differences, housing supply shocks are not able to explain a lot in the variances of property prices (and rents) for all four housing classes. The results illustrate that, contrary to popular belief, a higher supply of housing units does not help address the current housing affordability issue when it comes to becoming homeowners in Hong Kong, even though it may be beneficial to residents in the rental sector.

Besides the domestic factors, external factors (and/or exogenous shocks) are found to have varying effects on the prices/rents of housing units of different sizes. For the external factors, the conventional U.S. monetary policy, to a certain extent, does influence Hong Kong's housing market. Money supply (M1) shocks incur positive responses by both property prices and rents, especially those of larger housing flats (Classes C, D and E) (Figures 8i and 9i). This means that higher money supply is associated with higher property prices and rents, which is consistent with what has been found in the literature (Darrat \& Glascock, 1989; Breedon \& Joyce, 1992; Kim, 1993; Ball, 1994; Maclennan et al., 1998; Lastrapes, 2002; Aoki et al., 2004; Jin \& Zeng, 2004; Iacoviello, 2005; Chen et al., 2007, 2012; Elbourne, 2008; Goodhart \& Hofmann, 2008; Beltratti \& Morana, 2010). Yet, what distinguishes Hong Kong from other nations lies in the pegged exchange rate system, under which Hong Kong has no autonomy in decision-making with regard to money supply adjustments. In order to maintain the HKD-USD exchange rate within 7.75-7.85 HKD to 1 USD, new HKD has to be injected to Hong Kong's financial system should the USD depreciate, and vice versa. This is crucial, in view of the asset-purchase programme initiated by the Federal Reserve under which 3.5 trillions of new USD had been injected into the U.S. financial market for purchasing U.S. Treasuries since late $2008^{26}$. An unprecedented boost in money supply in the U.S., by virtue of the pegged exchange rate, has led to an equally-unprecedented increase in Hong Kong's money supply, which triggers significant responses in both property prices and rents. As indicated by the findings from the variance decomposition analysis, adjustments in M1 explain the largest price variances for larger flats (Classes $\mathrm{C}, \mathrm{D}$ and $\mathrm{E}$; from $6-7 \%$ ) and the largest rental variances for flats in Class A and Class C (more than 8\%).

Nonetheless, even though the relationship between stock market movements and property price/rental dynamics has been established, it does not necessarily mean that this additional housing demand, as a result of returns from a bullish market, is entirely investment-driven, considering that a continuously bullish stock market makes it much easier for prospective buyers to obtain, via gains from stock transactions, the capital necessary at least for the downpayment of flats. One way to ascertain the na-

\footnotetext{
${ }^{26} \mathrm{http}: / / \mathrm{www} . f e d e r a l r e s e r v e . g o v /$ monetarypolicy/bst_recenttrends.htm
} 
ture of such extra demand is through the two exogenous shock variables, in that demand shocks, by altering investor sentiments, usually adversely affect the investment demand for assets such as stocks, bonds, and housing. The AFC and SARS exogenous dummy variables do provide some justifications for this point, as they prompt negative impacts on housing prices (and rents) regardless of size. But, it should be noted that, the negative effects of these two variables are much larger among more spacious housing units (such as Classes C, D and E flats) (see Supplementary Appendixes 1-4). Through such disparities in the responses towards the same exogenous shocks, it thus

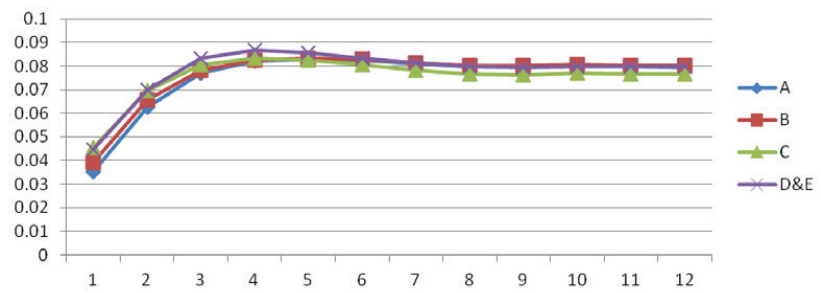

Figure 8a. Accumulated impulse response of PPI to shocks in lagged PPI

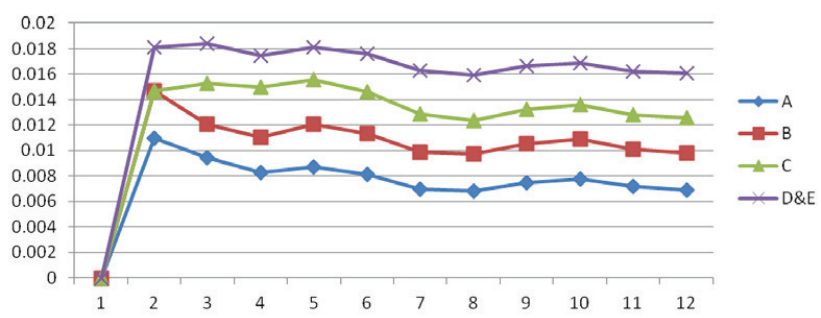

Figure 8b. Accumulated impulse response of PPI to shocks in Hang Seng Index

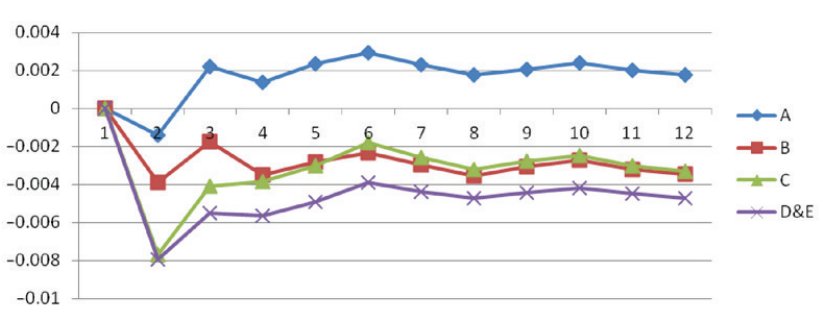

Figure 8c. Accumulated impulse response of PPI to shocks in stock market risk

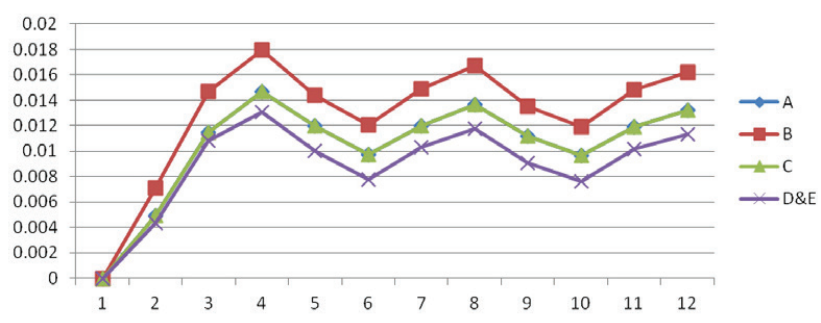

Figure 8d. Accumulated impulse response of PPI to shocks in real GDP can be reasonably stated that a higher proportion of the demand for larger housing units is investment-driven, as compared with that for smaller flats.

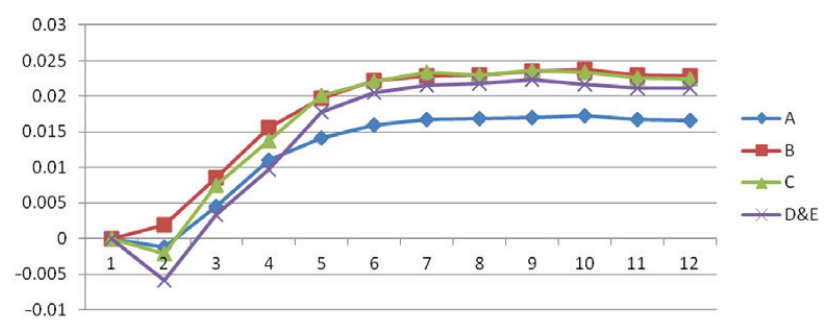

Figure 8e. Accumulated impulse response of PPI to shocks in the number of households

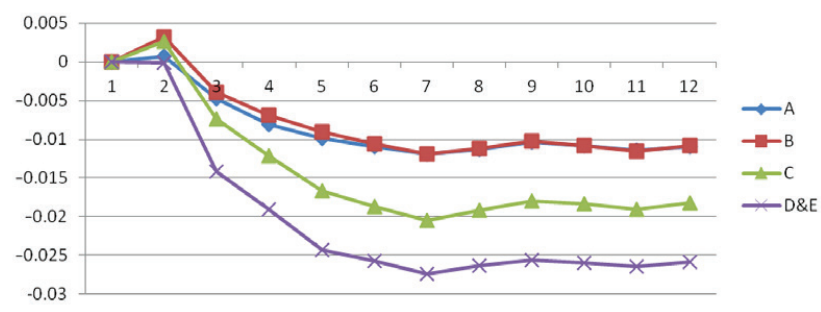

Figure 8f. Accumulated impulse response of PPI to shocks in CPI

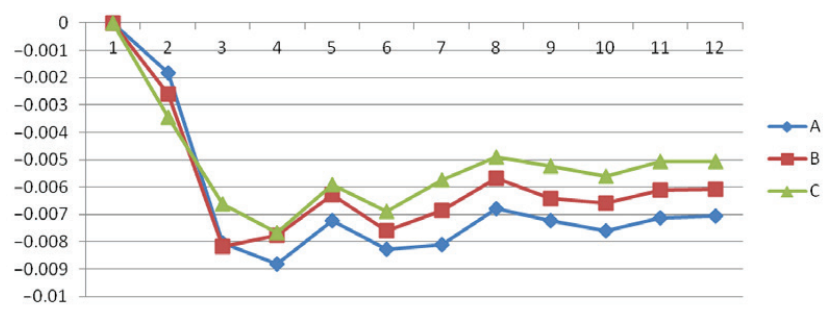

Figure 8g. Accumulated impulse response of PPI to shocks in the number of HOS flats transacted

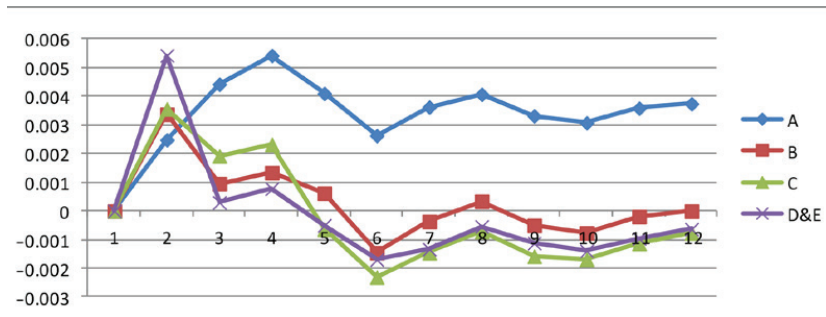

Figure 8h. Accumulated impulse response of PPI to shocks in housing supply

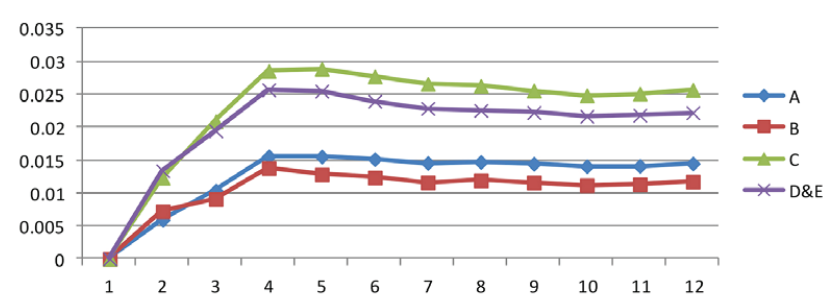

Figure 8i. Accumulated impulse response of PPI to shocks in money supply (M1) 


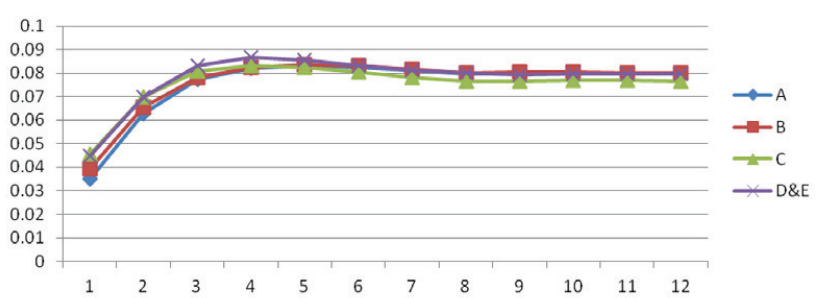

Figure 9a. Accumulated impulse response of PRI to shocks in lagged PRI

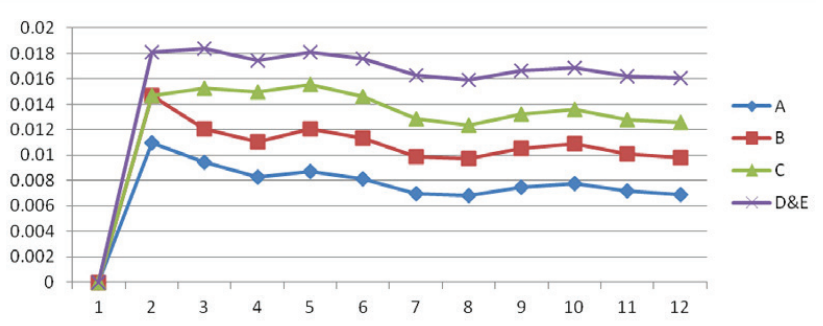

Figure 9b. Accumulated impulse response of PRI to shocks in Hang Seng Index

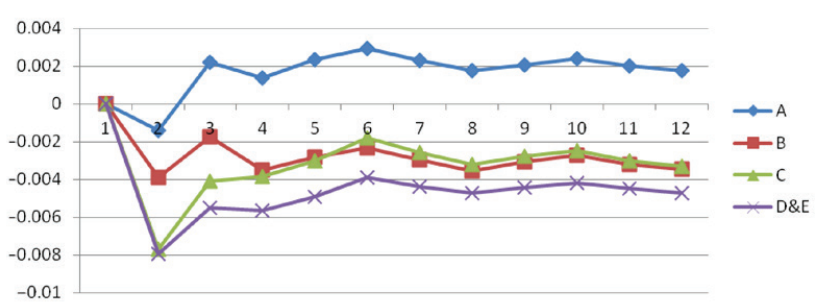

Figure 9c. Accumulated impulse response of PRI to shocks in stock market risk

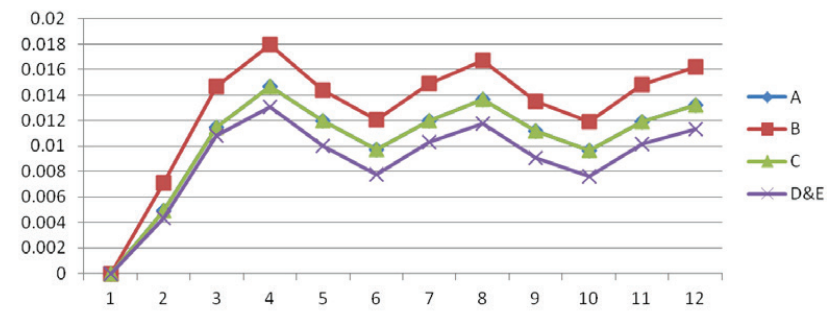

Figure 9d. Accumulated impulse response of PRI to shocks in real GDP

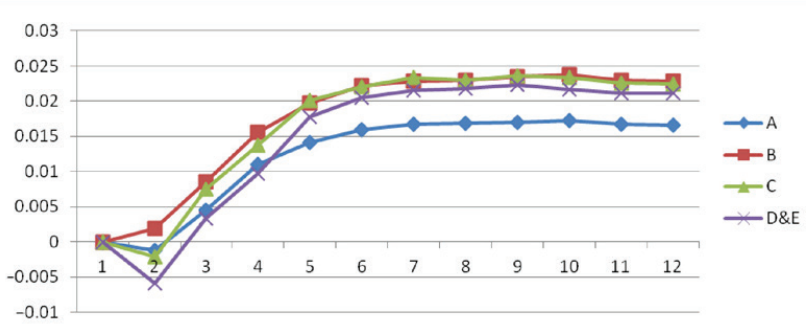

Figure 9e. Accumulated impulse response of PRI to shocks in the number of households

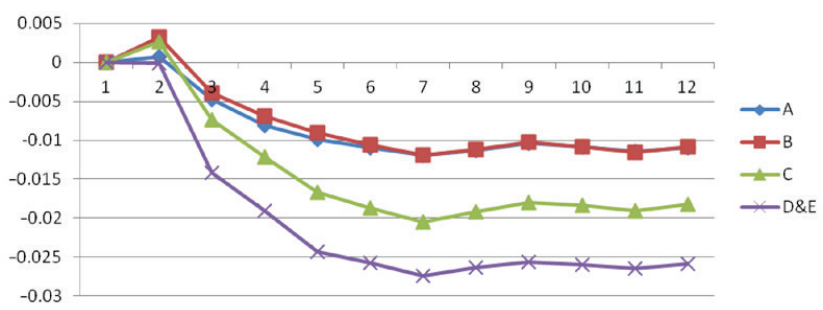

Figure 9f. Accumulated impulse response of PRI to shocks in CPI

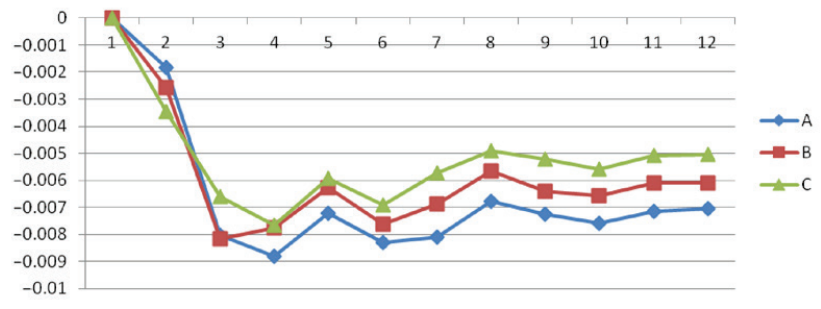

Figure 9g. Accumulated impulse response of PRI to shocks in the number of HOS flats transacted

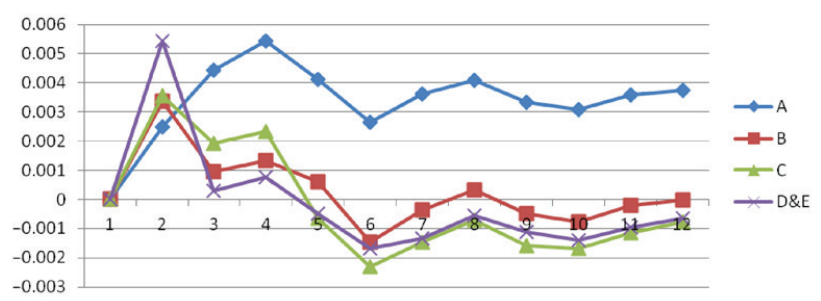

Figure 9h. Accumulated impulse response of PRI to shocks in housing supply

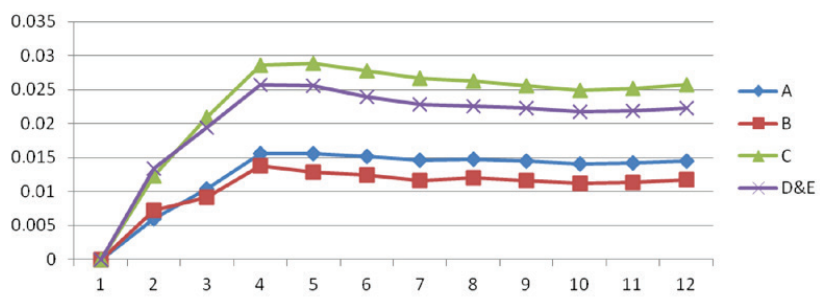

Figure 9i. Accumulated impulse response of PRI to shocks in money supply (M1)

\section{Conclusion and policy implications}

In light of the ever-escalating property price and rental levels in recent years, as well as calls for higher housing supply by the public, this paper has explored the significant determinants behind the price and rental movements of residential properties in Hong Kong. The findings show that, contrary to popular belief, changes in housing supply do not lead to significant adjustments in both property prices and rents. Instead, property prices and rents are essentially demand-driven. While household growth 
Table 3. Variance decomposition analysis results (Property price indices; in \%)

\begin{tabular}{|c|c|c|c|c|c|}
\hline & Period & Class A & Class B & Class C & Classes D \& E \\
\hline \multirow[t]{3}{*}{ Property price } & 4 & 82.56 & 78.42 & 73.29 & 70.93 \\
\hline & 8 & 80.97 & 76.43 & 70.64 & 68.58 \\
\hline & 12 & 80.37 & 75.70 & 69.89 & 68.22 \\
\hline \multirow[t]{3}{*}{ Real GDP } & 4 & 2.87 & 3.86 & 3.62 & 1.66 \\
\hline & 8 & 3.52 & 4.68 & 4.58 & 2.15 \\
\hline & 12 & 4.04 & 5.35 & 5.36 & 2.55 \\
\hline \multirow[t]{3}{*}{ CPI } & 4 & 1.54 & 2.29 & 3.46 & 5.58 \\
\hline & 8 & 1.71 & 2.53 & 4.05 & 6.17 \\
\hline & 12 & 1.76 & 2.58 & 4.08 & 6.17 \\
\hline \multirow[t]{3}{*}{ Amount of households } & 4 & 2.82 & 3.16 & 3.57 & 4.04 \\
\hline & 8 & 3.27 & 3.82 & 4.59 & 5.69 \\
\hline & 12 & 3.26 & 3.81 & 4.57 & 5.68 \\
\hline \multirow[t]{3}{*}{ Housing supply } & 4 & 0.41 & 0.57 & 0.41 & 1.41 \\
\hline & 8 & 0.58 & 0.76 & 0.72 & 1.45 \\
\hline & 12 & 0.61 & 0.78 & 0.74 & 1.46 \\
\hline \multirow[t]{3}{*}{ Money supply (M1) } & 4 & 3.04 & 2.52 & 7.47 & 6.39 \\
\hline & 8 & 2.99 & 2.51 & 7.23 & 6.24 \\
\hline & 12 & 2.98 & 2.50 & 7.19 & 6.22 \\
\hline \multirow[t]{3}{*}{ Hang Seng Index } & 4 & 4.61 & 7.21 & 5.66 & 8.24 \\
\hline & 8 & 4.57 & 7.12 & 5.55 & 7.99 \\
\hline & 12 & 4.57 & 7.10 & 5.53 & 7.98 \\
\hline \multirow[t]{3}{*}{ Stock market risk } & 4 & 0.58 & 0.74 & 1.91 & 1.75 \\
\hline & 8 & 0.64 & 0.77 & 1.92 & 1.73 \\
\hline & 12 & 0.65 & 0.78 & 1.92 & 1.73 \\
\hline \multirow[t]{3}{*}{ Amount of new HOS flats sold } & 4 & 1.58 & 1.23 & 0.61 & \\
\hline & 8 & 1.74 & 1.39 & 0.73 & \\
\hline & 12 & 1.75 & 1.40 & 0.74 & \\
\hline
\end{tabular}

Note: ${ }^{* *}$ denotes significance at $1 \%$ level; ${ }^{* *}$ at $5 \%$ level; and ${ }^{*}$ at $10 \%$ level.

Table 4. Variance decomposition analysis results (Property rental indices; in \%)

\begin{tabular}{|c|c|c|c|c|c|}
\hline & Period & Class A & Class B & Class C & Classes D \& E \\
\hline \multirow[t]{3}{*}{ Property rental } & 4 & 74.97 & 74.86 & 64.91 & 72.86 \\
\hline & 8 & 73.09 & 73.26 & 62.25 & 70.35 \\
\hline & 12 & 72.55 & 72.55 & 61.62 & 69.91 \\
\hline \multirow[t]{3}{*}{ Real GDP } & 4 & 1.83 & 1.79 & 4.25 & 2.59 \\
\hline & 8 & 2.49 & 3.11 & 5.45 & 3.31 \\
\hline & 12 & 3.02 & 3.84 & 6.20 & 3.75 \\
\hline \multirow[t]{3}{*}{ CPI } & 4 & 2.32 & 1.63 & 3.87 & 2.04 \\
\hline & 8 & 2.46 & 1.74 & 4.35 & 2.50 \\
\hline & 12 & 2.49 & 1.80 & 4.38 & 2.53 \\
\hline \multirow[t]{3}{*}{ Amount of households } & 4 & 0.36 & 0.38 & 1.02 & 3.38 \\
\hline & 8 & 0.65 & 0.58 & 1.80 & 4.35 \\
\hline & 12 & 0.67 & 0.62 & 1.81 & 4.35 \\
\hline \multirow[t]{3}{*}{ Housing supply } & 4 & 0.23 & 0.15 & 0.82 & 0.93 \\
\hline & 8 & 0.39 & 0.38 & 0.98 & 0.98 \\
\hline & 12 & 0.41 & 0.40 & 0.98 & 0.98 \\
\hline \multirow[t]{3}{*}{ Money supply (M1) } & 4 & 8.18 & 5.58 & 8.10 & 6.59 \\
\hline & 8 & 8.65 & 5.66 & 8.61 & 7.24 \\
\hline & 12 & 8.61 & 5.60 & 8.55 & 7.24 \\
\hline \multirow[t]{3}{*}{ Hang Seng Index } & 4 & 8.16 & 9.55 & 14.03 & 10.83 \\
\hline & 8 & 8.28 & 9.24 & 13.50 & 10.43 \\
\hline & 12 & 8.24 & 9.19 & 13.38 & 10.41 \\
\hline \multirow[t]{3}{*}{ Stock market risk } & 4 & 3.64 & 4.64 & 2.67 & 0.78 \\
\hline & 8 & 3.66 & 4.59 & 2.73 & 0.84 \\
\hline & 12 & 3.64 & 4.56 & 2.71 & 0.84 \\
\hline \multirow[t]{3}{*}{ Amount of new HOS flats sold } & 4 & 0.31 & 1.42 & 0.32 & \\
\hline & 8 & 0.33 & 1.43 & 0.33 & \\
\hline & 12 & 0.37 & 1.45 & 0.36 & \\
\hline
\end{tabular}


and real GDP growth influence movements in both prices and rents of residential properties, inflation rate only yields significant impact specific housing sub-markets (for instance, price of luxury flats and rent of Class C flats). The provision of assisted homeownership is also found to incur significant effects, in that the sale of new HOS flats, in particular affect prices of Class A units and that transaction of HOS flats induces positive impact on the rents of mid-size flats (Class C). More importantly, both prices and rents of residential units in all classes are highly subject to U.S. monetary policy measures, both directly and indirectly. The direct effects come from adjustments in money supply (primarily on the prices of larger housing units such as Classes C, D and E flats); whereas the indirect effects originate from the wealth effect from a bullish stock market, which in turn has been fuelled by the portfolio rebalancing effect (see Tobin, 1969; Joyce, Lasaosa, Stevens, \& Tong, 2011; Gagnon, Raskin, Remache, \& Sack, 2011; Bernanke, 2012; Hamilton \& Wu, 2012) and/or the signaling effect (see Bauer \& Rudebusch, 2011) as a result of the QE.

Taking these findings into account, there are a number of policy implications worth discussing. The first implication concerns the general belief that "a higher housing supply is able to address the current housing affordability issue". As reported in previous sections, changes in the supply of housing in the private sector do not incur noticeable responses by property prices/rents in all sub-classes of housing. In other words, the empirical findings neither confirm nor reject this belief, since its impact on housing price (and/or rent) is at best minimal. The availability of HOS flats, however, could help meet this objective to a certain extent. It has been shown that the availability of HOS flats serves as an alternative to private housing units, especially Classes A and B flats. By absorbing a fraction of demand for private housing, the availability of more HOS units is able to curb the upward price trend of these smaller flats in the private sector.

The other two implications are related to the Linked Exchange Rate system. Firstly, following the end of QE in late October of 2014, the Federal Reserve eventually ended the ZIRP, as the Federal Funds Rate was raised by $0.25 \%{ }^{27}$ (to $0.25-0.5 \%$ per annum). This was immediately followed by a base rate hike by the same amount in Hong Kong. For Hong Kong's housing market, a more immediate effect would be on mortgages, as higher interest rates indicate higher costs for floating-rate mortgage loans. This, theoretically, reduces the incentives of people to become homeowners. The end of the ZIRP, in addition, also has implications on money supply. Since the Global Financial Crisis of 2008, the Federal Reserve, besides having introduced the ZIRP, had also purchased approximately 3.5 trillion USD worth of U.S. Treasuries, in the process of which injecting the same amount of newly-printed money

\footnotetext{
${ }^{27}$ It was also predicted by Federal Reserve officials to reach approximately $1.375 \%$ by the end of 2016 .
}

into the financial system. This has resulted in much higher international asset prices and the depreciation of the U.S. $\operatorname{Dollar}^{28}$ (Neely, 2015). For Hong Kong, it has led to 1) the inflow of massive amounts of hot money (from abroad) in pursuit of investment opportunities and 2) a massive increase in Hong Kong's own money supply by virtue of the pegged exchange rate arrangement. As confirmed in previous sections, it is the capital appreciations from a bullish stock market, fuelled by this unconventional monetary policy, that cause substantial growth in property prices/ rents via the wealth effect. A rise in the U.S.'s interest rate $^{29}$, however, strengthens the U.S. Dollar while reducing the level of liquidity in the financial system ${ }^{30}$, as the Federal Reserve, in essentially a reserve repo operation, needs to drain billions of U.S. dollars away from the financial system in order to maintain the newly-adjusted Federal Funds Rate. This could trigger large-scale capital outflow from countries outside the U.S. especially among bond investors ${ }^{31}$ (and thus falling equity prices on a global scale). In Hong Kong, due to the pegged exchange rate, an

${ }^{28}$ From a broader perspective, this also means the depreciation of the Hong Kong Dollar (until the just-announced rise in U.S. interest rate) against other non-U.S. currencies, in particular China's Renminbi. This has led to imported inflation due to more expensive necessities primarily imported from Mainland China. A higher level of (imported) inflation, besides compromising Hong Kong residents living standards, has been found to have significant impact on the rental sector of the mass housing market, the HOS resale market, and the stock market (which leads to further circulation of capital within and thus the subsequent generation of additional housing demand). Oppositely, a strengthened U.S. Dollar likely results in (imported) deflationary pressure, as imports become cheaper.

${ }^{29}$ The end of ZIRP could lead to changes in terms of mortgage arrangements in Hong Kong as well. Ever since the introduction of ZIRP on December $16^{\text {th }}, 2008$, mortgages based upon the HIBOR-rate which is linked to the Federal Funds Rate have become very popular among new homebuyers, in comparison with mortgages based upon the best lending rate, according to statistics provided by the HKMA. The end of ZIRP (along with the subsequent interest rate hikes) indicates that the cost differences between HIBOR-rate mortgages and best lending rate mortgages would gradually converge, and the fluctuating nature of the HIBOR rate could render the former a less preferable (and riskier) choice among potential homebuyers in the future.

${ }^{30}$ The impact of rising Fed rates on global liquidity, however, would be offset to a certain degree, due to Japan's re-launch of Quantitative Easing since April 2013 and of the European Central Bank's introduction of its asset-purchase programme since March 2015.

${ }^{31}$ A stronger U.S. Dollar (and Federal Funds rate hikes) raises the cost of repayment for global debts and bonds denominated in the currency, thus increasing their default risks (and/ or incentives to raise capital for investment). According to a recently-published Banks for International Settlements report (McCauley, McGuire, \& Sushko, 2015), the outstanding U.S. dollar credit to non-bank borrowers outside the U.S., since the 2008 global financial crisis, has soared from 6 trillion to 9 trillion USD. 
increase in the Federal Funds Rate could incur downward adjustments in money supply (and an increase in Hong Kong's own interest rate) which have been shown to result in lower property prices and rents.

In other words, the current housing affordability issue is essentially a by-product of (unconventional) U.S. monetary policy decisions via the Linked Exchange Rate system. This, along with uncontainable asset price hikes and imported inflation, has raised some doubts as to whether the drawbacks of the pegged exchange rate arrangement have already outweighed its advantages (such as stability in exchange rates), and whether the system itself (or at least the "hard peg" version of it) is still worth maintaining.

\section{References}

AETM. (1991). Determinants of the prices of established housing. A report published by Applied Economics PTY LTD and Travers Morgan PTY LTD, Australia.

Aoki, K., Proudman, J., \& Vlieghe, G. (2004). House prices, consumption, and monetary policy: a financial accelerator approach. Journal of Financial Intermediation, 13(4), 414-435. https://doi.org/10.1016/j.jfi.2004.06.003

Arnott, R. (1987). Economic theory and housing. In E. S. Mills (Ed.), Handbook of regional urban economics, Vol. 2 Urban economics (pp. 959-988). New York: Elsevier Science Publishing.

Arrondela, L., \& Lefebvreb, B. (2001). Consumption and investment motives in housing wealth accumulation: a French study. Journal of Urban Economics, 50(1), 112-137.

https://doi.org/10.1006/juec.2000.2209

Bacher, J. (1993). Keeping to the marketplace: the evolution of $\mathrm{Ca}$ nadian housing policy. Montreal: McGill-Queen's University Press.

Balchin, P. (Ed.). (1996). Housing policy in Europe. London: Routledge. https://doi.org/10.4324/9780203436417

Ball, M. (1994). The 1980s property boom. Environment and Planning A, 26, 671-695. https://doi.org/10.1068/a260671

Bardhan, A. D., Datta, R., Edelstein, R. H., \& Lum, S. K. (2003). A tale of two sectors: upward mobility and the private housing market in Singapore. Journal of Housing Economics, 12(2), 83-105. https://doi.org/10.1016/S1051-1377(03)00016-0

Bauer, M. D., \& Rudebusch, G. D. (2011). The signaling channel for Federal Reserve bond purchases. Federal Reserve Bank of San Francisco Working Paper 2011-21.

Beltratti, A., \& Morana, C. (2010). International house prices and macroeconomic fluctuations. Journal of Banking and Finance, 34, 533-545. https://doi.org/10.1016/j.jbankfin.2009.08.020

Berkovec, J. (1989). A general equilibrium model of housing consumption and investment. Journal of Real Estate Finance and Economics, 2(3), 157-172.

https://doi.org/10.1007/BF00152345

Bernanke, B. S. (2012). Monetary policy since the onset of the crisis. Speech at the Federal Reserve Bank of Kansas City Economic Symposium, 31 August 2012.

Bosworth, B., Burtless, G., \& Sabelhaus, J. (1991). The decline in saving: evidence from household surveys. Brookings Papers on Economic Activity, 1, 183-241. https://doi.org/10.2307/2534640

Bourassa, S. C., \& Hendershott, P. H. (1995). Australian capital city real housing prices, 1979-1993. Australian Economic Review, 3, 16-26.

https://doi.org/10.1111/j.1467-8462.1995.tb00990.x
Breedon, F., \& Joyce, M. A. S. (1992). House prices, arrears, and possessions. Bank of England Quarterly Bulletin (pp. 173-179).

Brueckner, J. K. (1997). Consumption and investment motives and the portfolio choices of homeowners. Journal of Real Estate Finance and Economics, 15(2), 159-180. https://doi.org/10.1023/A:1007777532293

Buckley, R., \& Ermisch, J. F. (1982). Theory and empiricism in the econometric modelling of house prices. Urban Studies, 20(1), 83-90. https://doi.org/10.1080/713703151

Case, B., Goetzmann, W., \& Rouwenhorst, K. G. (1999). Global real estate markets - cycles and fundamentals. Working Paper, No. 7/99. Yale International Center for Finance.

Case, K. E., \& Shiller, R. J. (1989). The efficiency of the market for single family homes. American Economic Review, 79(1), 125-137.

Cassidy, H. J., Dennis, B., \& Yang, T. T. (2008). Home appreciation participation notes: a solution to housing affordability and the current mortgage crisis. International Real Estate Review, 11(2), 126-141.

Chen, M. C., Chang, C. O., Yang, C. Y., \& Hsieh, B. M. (2012). Investment demand and housing prices in an emerging economy. Journal of Real Estate Research, 34(3), 345-373.

Chen, M. C., \& Patel, K. (2002). An empirical analysis of determination of house prices in the Taipei area. Taiwan Economic Review, 30(4), 563-595. https://doi.org/10.6277/ter.2002.304.5

Chen, M. C., Tsai, I. C., \& Chang, C. O. (2007). House prices and household income: do they move apart? Evidence from Taiwan. Habitat International, 31, 243-256. https://doi.org/10.1016/j.habitatint.2007.02.005

Ching, L. K., \& Tyabji, A. (1991). Homeownership policy in Singapore: an assessment. Housing Studies, 6(1), 15-28. https://doi.org/10.1080/02673039108720694

Corsetti, G., Pesenti, P., \& Roubini, N. (1999). What caused the Asian currency and financial crisis? Federal Reserve Bank of New York. Retrieved from https://www.newyorkfed.org/medialibrary/media/research/economists/pesenti/whatjapwor.pdf

Darrat, A. F., \& Glascock, J. L. (1989). Real estate returns, money and fiscal deficits: is the real estate market efficient?. Journal of Real Estate Finance and Economics, 2, 197-208. https://doi.org/10.1007/BF00152348

Drake, L. (1993). Modelling UK house prices using cointegration: an application of the Johansen technique. Applied Economics, 25, 1225-1228. https://doi.org/10.1080/00036849300000183

Elbourne, A. (2008). The U.K. housing market and the monetary policy transmission mechanism: an SVAR approach. Journal of Housing Economics, 17, 65-87.

https://doi.org/10.1016/j.jhe.2007.09.002

Fama, E. F. (1990). Stock returns, expected returns, and real activity. Journal of Finance, 45(4), 1089-1108. https://doi.org/10.1111/j.1540-6261.1990.tb02428.x

Forrest, R., \& Murie, A. (1988). Selling the welfare state, the privatization of public housing. London: Routledge.

Forrest, R., Murie, A., \& Williams, P. (1990). Homeownership: differentiation and fragmentation. London: Unwin Hyman.

Gagnon, J., Raskin, M., Remache, J., \& Sack, B. (2011). Largescale asset purchases by the Federal Reserve: did they work?. Economic Policy Review, 17(1), 41-59.

Garfinkel, M. R., \& Thornton, D. L. (1989). The link between M1 and monetary base in the 1980s. Federal Reserve Bank of St Louis. Retrieved from https://research.stlouisfed.org/publications/review/89/09/Link_Sep_Oct1989.pdf

Geske, R.; Roll, R. (1983). The fiscal and monetary linkage between stock returns and inflation. Journal of Finance, 28(1), 7-33. https://doi.org/10.1111/j.1540-6261.1983.tb03623.x 
Gibson, W. E. (1972). Interest rates and inflationary expectations: new evidence. American Economic Review, 62(5), 854-865.

Goodhart, C., \& Hofmann, B. (2008). House prices, money, credit, and the macroeconomy. Oxford Review of Economic Policy, 24(1), 180-205. https://doi.org/10.1093/oxrep/grn009

Hamilton, J. D., \& Wu, J. C. (2012). The effectiveness of alternative monetary policy tools in a zero lower bound environment. Journal of Money, Credit and Banking, 44(1), 3-46.

Hays, R. (1994). Housing privatization: social goals and policy strategies. Journal of Urban Affairs, 16(4), 295-317. https://doi.org/10.1111/j.1467-9906.1994.tb00332.x

Henderson, J. V., \& Ioannides, Y. M. (1983). A model of housing tenure choice. American Economic Review, 73(1), 98-113.

Henderson, J. V., \& Ioannides, Y. M. (1987). Ownership occupancy: investment vs consumption demand. Journal of Urban Economics, 21, 228-241.

https://doi.org/10.1016/0094-1190(87)90016-7

Hoesli, M., Lizieri, C., \& MacGregor, B. (2008). The inflation hedging characteristics of U.S. and U.K. investments: a multifactor error correction approach. Journal of Real Estate Finance and Economics, 36, 183-206.

https://doi.org/10.1007/s11146-007-9062-6

Hui, C. M., Yu, K. H., \& Ho, K. H. (2009). Dynamics of assisted home ownership in Singapore dynamics of assisted home ownership in Singapore. Journal of Urban Affairs, 31(2), 197-215.

Hui, E. C. M., \& Yiu, C. Y. (2003). Market dynamics of private residential real estate price - an empirical test in Hong Kong. Journal of Financial Management of Property and Construction, 8(3), 155-165.

Iacoviello, Y. M. (2005). House prices, borrowing constraints, and monetary policy in the business cycle. American Economic Review, 95(3), 739-764. https://doi.org/10.1257/0002828054201477

Ito, T., \& Iwaisako, T. (1995). Explaining asset bubbles in Japan. Working Paper. International Monetary Fund.

Jin, Y., \& Zeng, Z. (2004). Residential investment and house prices in a multi-sector monetary business cycle model. Journal of Housing Economics, 13, 268-286.

https://doi.org/10.1016/j.jhe.2004.08.001

Joyce, M., Lasaosa, A., Stevens, I., \& Tong, M. (2011). The financial market impact of quantitative easing in the United Kingdom. International Journal of Central Banking, 7(3), 113-161.

Kaul, G. (1987). Stock returns and inflation: the role of the monetary sector. Journal of Financial Economics, 18(2), 253-276. https://doi.org/10.1016/0304-405X(87)90041-9

Kim, K. H. (1993). Housing prices, affordability, and government policy in Korea. Journal of Real Estate Finance and Economics, 6, 55-71. https://doi.org/10.1007/BF01098428

La Grange, A., \& Pretorius, F. (2000). Ontology, policy and the market: trends to home-ownership in Hong Kong. Urban Studies, 37(9), 1561-1582.

https://doi.org/10.1080/00420980020080261

Lastrapes, W. D. (2002). The real price of housing and money supply shocks: time series evidence and theoretical simulations. Journal of Housing Economics, 11(1), 40-74. https://doi.org/10.1006/jhec.2002.0309

Lee, J. K. C. (1996). Homeownership, consumption and social divisions in Hong Kong: a theoretical and empirical note. In S. K. Lau (Ed.), New frontiers of social indicators research in Chinese societies (pp. 235-264). Hong Kong: Chinese University of Hong Kong Press.

Lee, S. H. (2003). The SARS epidemic in Hong Kong. Journal of Epidemiology and Community Health, 57, 652-654. https://doi.org/10.1136/jech.57.9.652
Lin, C. C., \& Lin, S. J. (1999). An estimation of elasticities of consumption demand and investment demand for owneroccupied housing in Taiwan: a two-period model. Journal of Real Estate Review, 2(1), 110-125.

Ling, D., \& Narnjo, A. (1995). An analysis of the linkages between macroeconomic events and commercial real estate returns. Proceeding of the RICS Property Research Conference, The Cutting Edge, Vol. 1, 281-304.

Linneman, P. (1986). An empirical test of the efficiency of the housing market. Journal of Urban Economics, 20, 140-154. https://doi.org/10.1016/0094-1190(86)90003-3

Lum, S. K. (1996). The Singapore private property market - price trends and affordability. Paper presented at the Conference on the Singapore Dream: private property, social expectations and public policy, 6 September 1996. National University of Singapore.

Maclennan, D., Muellbauer, J., \& Stephens, M. (1998). Asymmetries in housing and financial market institutions and EMU. Oxford Review of Economic Policy, 14(3), 54-80. https://doi.org/10.1093/oxrep/14.3.54

Malpezzi, S. (1996). Housing prices, externalities, and regulation in U.S. metropolitan areas. Journal of Housing Research, 7(2), 209-241.

Manchester, J. M., \& Poterba, J. M. (1989). Second mortgages and household saving. Regional Science and Urban Economics, 19, 325-346. https://doi.org/10.1016/0166-0462(89)90009-4

McCauley, R. N., McGuire, P., \& Sushko, V. (2015). Global dollar credit: links to US monetary policy and leverage. Bank for International Settlements Working Papers No. 483. Retrieved from http://www.bis.org/publ/work483.pdf

Munro, M., \& Tu, Y. (1996). The dynamics of UK national and regional house prices. Review of Urban and Regional Development Studies, 8, 186-201. https://doi.org/10.1111/j.1467-940X.1996.tb00117.x

Ong, S. E. (1999). Housing affordability and upward mobility from public to private housing in Singapore. Paper presented to the Workshop on Housing Policy in Emerging Economies. Singapore.

Ong, S. E. (2000). Housing affordability and upward mobility from public to private housing in Singapore. International Real Estate Review, 3(1), 49-64.

Ong, S. E., \& Sing, T. F. (2002). Price discovery between private and public housing markets. Urban Studies, 39(1), 57-67. https://doi.org/10.1080/00420980220099069

Pain, N., \& Westaway, P. (1997). Modelling structure change in the United Kingdom housing market: a comparison of alternative house price models. Economic Modelling, 14(4), 587610. https://doi.org/10.1016/S0264-9993(97)00007-2

Phang, S. Y., \& Wong, W. K. (1997). Government policies and private housing prices in Singapore. Urban Studies, 34(11), 1819-1829. https://doi.org/10.1080/0042098975268

Pickvance, C. (1994). Housing privatization and housing protest in the transition from state socialism: a comparative study of Budapest and Moscow. International Journal of Urban and Regional Research, 18, 433-450.

https://doi.org/10.1111/j.1468-2427.1994.tb00277.x

Ritakallio, V. M. (2003). The importance of housing costs in cross-national comparisons of welfare (state) outcomes. International Social Security Review, 56, 81-101. https://doi.org/10.1111/1468-246X.00159

Saunders, P. (1990). A nation of home owners. London: Unwin Hyman.

Schwab, R. (1983). Real and nominal interest rates and the demand for housing. Journal of Urban Economics, 13, 181-195. https://doi.org/10.1016/0094-1190(83)90004-9 
Sirmans, G. S., \& Sirmans, C. F. (1987). The historical perspective of real estate returns. Journal of Portfolio Management, 13(3), 2-31. https://doi.org/10.3905/jpm.1987.409109

Skinner, J. (1989). Housing wealth and aggregate saving. Regional Science and Urban Economics, 19, 305-324. https://doi.org/10.1016/0166-0462(89)90008-2

Stern, D. (1992). Explaining UK house price inflation 1971-89. Applied Economics, 24, 1327-1333. https://doi.org/10.1080/00036849200000093

Teo, S. E., \& Kong, L. (1997). Public housing in Singapore: interpreting "Quality" in the 1990s. Urban Studies, 34(11), 441452.

Tobin, J. (1969). A general equilibrium approach to monetary theory. Journal of Money, Credit and Banking, 1(1), 15-29. https://doi.org/10.2307/1991374

Tu, Y. (2000). Segmentation of Australian housing markets: 1989-98. Journal of Property Research, 17(4), 311-327. https://doi.org/10.1080/09599910010001420
$\mathrm{Tu}, \mathrm{Y}$. (2002). The impacts of public resold dwellings on the private housing prices: Singapore experiences. Working Paper. Department of Real Estate, National University of Singapore.

Tu, Y., Kwee, L. K., \& Yuen, B. K. P. (2002). Modelling Singapore households' social mobility behaviour: from public homeownership to private homeownership. Working Paper. Department of Real Estate, National University of Singapore.

Whitehead, C. (1974). The UK housing market: an econometric model. London: Saxon House.

Yiu, C. Y. (2009). Negative real interest rate and housing bubble implosion - an empirical study in Hong Kong. Journal of Financial Management of Property and Construction, 14(3), 257-270. https://doi.org/10.1108/13664380911000477

Zerbst, R. H., \& Cambon, B. R. (1984). Historical returns on real estate investment. Journal of Portfolio Management, 10, 5-20. https://doi.org/10.3905/jpm.1984.408959 